
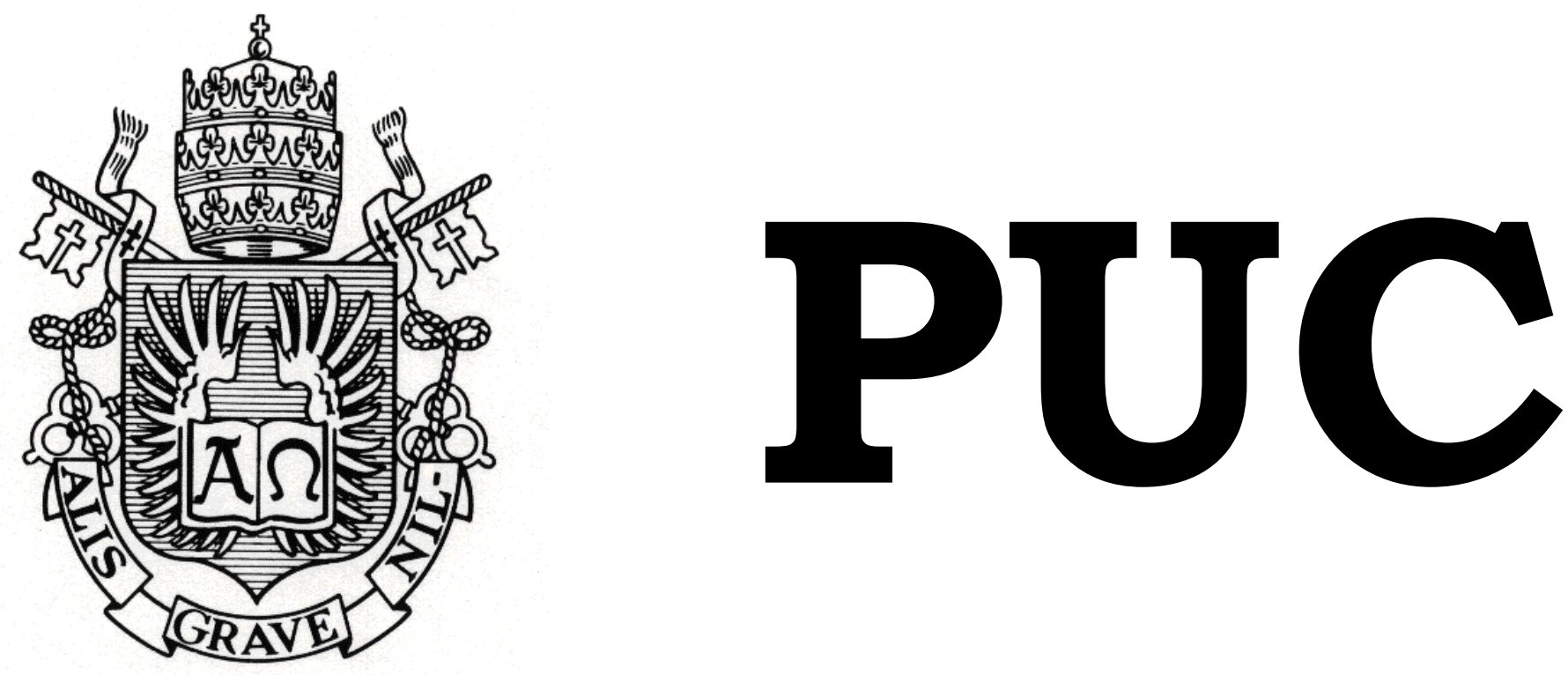

DEPARTAMENTO DE DIREITO

\title{
DOS PORÕES À CORTE \\ INTERAMERICANA DE DIREITOS \\ HUMANOS: DESAFIOS DA ANISTIA
}

por

RODRIGO SANTA MARIA COQUILLARD AYRES

ORIENTADOR(A): OTÁVIO BRAVO

2010.2

PONTIFÍCIA UNIVERSIDADE CATÓLICA DO RIO DE JANEIRO

RUA MARQUÊS DE SÃO VICENTE, 225 - CEP 22453-900

RIO DE JANEIRO - BRASIL 


\title{
DOS PORÕES À CORTE INTERAMERICANA DE DIREITOS HUMANOS: DESAFIOS DA ANISTIA
}

\author{
por \\ RODRIGO SANTA MARIA COQUILLARD AYRES
}

Monografia

apresentada

ao

Departamento de Direito da Pontificia Universidade Católica do Rio de Janeiro (PUC-Rio) para a obtenção do Título de Bacharel em Direito.

Orientador(a): Otávio Bravo

2010.2 
Primeiramente a Deus, por mais esta oportunidade.

Aos que lutaram, especialmente aos que sofreram.

Aos meus pais, pelo amor e apoio incondicionais.

Ao meu irmão, pela mais pura e eterna amizade. 


\section{AGRADECIMENTOS}

Ao meu pai Antonio Gil Ayres, pessoa que tanto amo e admiro por inesgotáveis motivos. À minha mãe Lygia Ayres, pelo seu exemplo de humanidade e amor materno, que nunca me faltou. Ao meu irmão Antonio Felipe, pela sua alegre e incentivadora presença. Sem eles, este passo não teria sido dado.

Ao professor Otávio Bravo, pela confiança e empenho dedicados a esta monografia, sua orientação foi extremamente valiosa.

A todos que de algum modo contribuíram para a feitura do presente estudo, sem jamais esquecer - é claro - dos que lutaram para que estas páginas não viessem a ser censuradas. Muito obrigado. 


\section{RESUMO}

A presente monografia teve por finalidade estudar os principais fundamentos jurídicos utilizados na defesa da responsabilização penal dos autores de crimes contra a humanidade praticados durante a ditadura militar no Brasil. Após uma contextualização histórica dos fatos e das torturas, foram expostas as argumentações invocadas na ADPF $n^{\circ} 153$, em que o Supremo Tribunal Federal entendeu estarem também anistiados pela Lei $\mathrm{n}^{\mathbf{o}}$ 6.693/79 (Lei de Anistia) os torturadores a serviço da repressão política. Após problematizar a decisão proferida pelo STF, analisou-se o Caso Guerrilha do Araguaia x Brasil, em trâmite na Corte Interamericana de Direitos Humanos, cuja decisão pode condenar o Brasil a promover a persecução penal de tais crimes. Diante de uma eventual sentença de procedência, algumas páginas foram dedicadas às possíveis consequências desta condenação face o direito interno, especialmente no que tange à sua execução. Assim, reconhece-se a necessidade do Estado brasileiro acertar as suas contas com o passado autoritário, sendo uma questão fundamental na defesa dos direitos humanos e da democracia. É preciso arrebentar as correntes que nos ligam ao regime ditatorial, objetivando justamente a não repetição de um pretérito tão tenebroso como os anos de 1964 a 1985.

\section{Palavras - chave:}

Anistia; Tortura; Ditadura Militar; Direitos Humanos; Justiça Transicional; Transição; Golpe de 1964; Desaparecidos Políticos; Guerrilha; Araguaia; Convenção Americana; Pacto de São José da Costa Rica; Memória; Corte Interamericana; 


\section{SUMÁRIO}

INTRODUÇÃO

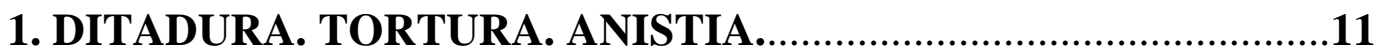

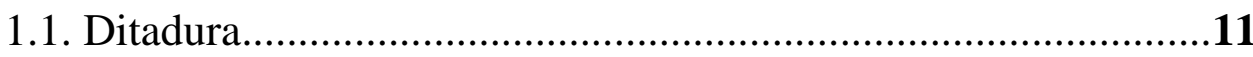

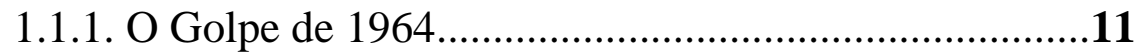

1.1.2. A ditadura militar......................................................14

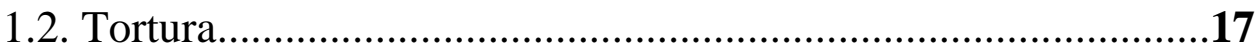

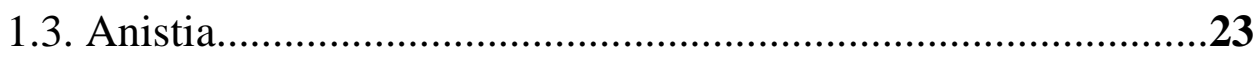

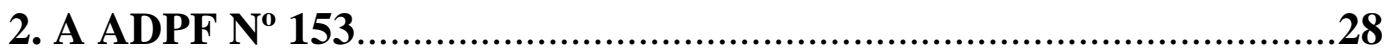

2.1. Dos fundamentos da inicial.......................................................28

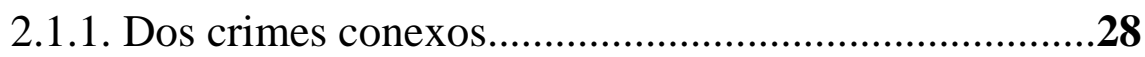

2.1.2. Da invalidade...........................................................

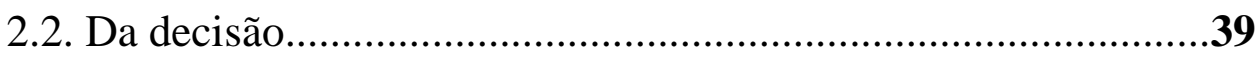

2.1.2. Contextualização..........................................................39

2.1.2. Voto do Ministro Eros Grau............................................40

2.1.3. Voto da Ministra Cármen Lúcia.......................................43

2.1.4. Voto do Ministro Ricardo Lewandowsky......................44

2.1.5. Voto do Ministro Ayres Britto.........................................45

2.1.6. Votos dos Ministros Ellen Gracie e Marco Aurélio.....47

2.1.7. Voto do Ministro Celso de Mello......................................47

2.1.8. Voto do Ministro Cezar Peluso........................................48 
2.1.9. Voto do Ministro Gilmar Mendes...................................48

2.1.10. Breves considerações...................................................48

3. A CORTE INTERAMERICANA DE DIREITOS HUMANOS.......52

3.1. Caso Guerrilha do Araguaia x Brasil.........................................52

3.1.1. A Guerrilha do Araguaia..............................................52

3.1.2. A Convenção Americana de Direitos Humanos...........55

3.1.3. Da competência da Corte...............................................58

3.1.4. Dos crimes contra a humanidade..................................59

3.1.5. Da obrigação de investigar.............................................61

3.1.6. Dos direitos violados...................................................63

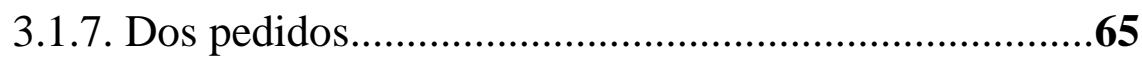

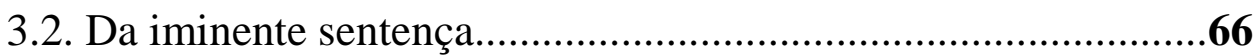

3.2.1. Das possibilidades......................................................66

3.2.2. Da hierarquia dos tratados.............................................68

3.2.3. Convenção Americana x Lei de Anistia..........................72

3.2.4. Do cumprimento...........................................................74

3.2.5. Da inadimplência.............................................................

4. CONCLUSÃO

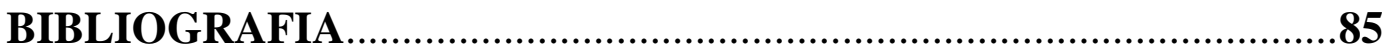




\section{ABREVIATURAS}

ADCT Ato das Disposições Constitucionais Transitórias

ADIN Ação Declaratória de Inconstitucionalidade

ADPF Arguição de Descumprimento de Preceito Fundamental

AI

Ato Institucional

ARENA Aliança Renovadora Nacional

CIDH Comissão Interamericana de Direitos Humanos

CODI Centro de Operações de Defesa Interna

DJ Diário da Justiça

DOI Destacamento de Operações de Informações

DOPS Departamento de Ordem Política e Social

EC Emenda Constitucional

ESG Escola Superior de Guerra

Ibid. Ibidem

LSN Lei de Segurança Nacional

MDB Movimento Democrático Brasileiro

OAB Ordem dos Advogados do Brasil

OEA Organização dos Estados Americanos

ONU Organização das Nações Unidas

PC do B Partido Comunista do Brasil

PCB Partido Comunista Brasileiro

PE Polícia do Exército

RE Recurso Extraordinário

RTJ Revista Trimestral de Jurisprudência do Supremo Tribunal Federal

STF Supremo Tribunal Federal

STM Superior Tribunal Militar

TPII Estatuto do Tribunal Penal Internacional para os Crimes cometidos na ex-Iugoslávia 


\section{INTRODUÇÃO}

Bem-aventurados os que sofrem perseguição por causa da justiça, porque deles é o reino dos céus (Evangelho de Jesus Cristo segundo Mateus 5, 10)

A ditadura militar foi um dos períodos mais cruéis e - por isso importantes da História do Brasil. Daí que muitos de seus acontecimentos ainda continuam ocultos ou sem explicação, principalmente os relacionados aos crimes cometidos pela repressão política. Juridicamente, isto se dá porque a lei no 6.683/79 (Lei de Anistia) sempre impediu a investigação de tais fatos, enquanto a Lei $\mathrm{n}^{\circ} 11.111 / 05$ reforçou o sigilo dos principais documentos da ditadura. Por conseguinte, é inevitável que muitas perguntas encontrem-se sem respostas. Há, inclusive, muitas respostas sem perguntas. Entre perguntas e respostas subsiste o fantasma do desaparecido político: não está vivo - presume-se - mas nunca se viu o corpo. O Estado não assume sua morte, muito embora existam diversas testemunhas de sua prisão e tortura. O Estado vai além: nega inclusive a sua prisão. Sumiu. Onde está o desaparecido político? O Brasil tem o dever de responder esta pergunta. Aliás, não só de respondê-la, mas de entregar o seu corpo aos familiares para a realização de um funeral, em respeito ao direito natural de enterrar os mortos - como já pleiteava Antígona, na tragédia grega de Sófocles. Enquanto não se vive o luto, não há morte; contudo, vida também não há. A figura do desaparecido político é um dos resultados mais perversos que a ditadura militar produziu - e a atual democracia perpetua -, condenando familiares a sofrer até os seus últimos dias de vida, muitas vezes esperando a volta milagrosa de um filho assassinado na tortura. Neste triste cenário, mais de uma centena de militantes políticos ainda continua desaparecida. A verdade é que estas lacunas da História existem porque nunca houve uma investigação dos fatos. Assim, seguindo um contexto de crescente preocupação com os direitos humanos na comunidade universal, 
verifica-se o fortalecimento do debate acerca da "mudança de modelo (da anistia para a responsabilização e a busca da verdade)" ${ }^{\text {1 }}$ da justiça de transição no Brasil, ou seja, das medidas ${ }^{2}$ que devem ser adotadas para reparar as violações de direitos humanos ocorridas no passado, pretendendo evitar que se repitam. Um destes instrumentos é o chamado direito à justiça, consubstanciado na obrigação que o Estado tem de investigar os crimes contra a humanidade, possibilitando inclusive o esclarecimento dos fatos por meios das investigações. Obviamente, a aplicação deste postulado no direito brasileiro instaura um conflito direto com a Lei de Anistia. Nesta toada, o presente trabalho procurou examinar os mecanismos pelos quais a viabilidade jurídica desta responsabilização vem sendo pleiteada. Analisarse-ão os fundamentos da $\mathrm{ADPF} \mathrm{n}^{\circ} 153$, em que se requereu uma declaração do Supremo Tribunal Federal contrária à anistia aos crimes da repressão política. O STF, embora tenha julgado o pedido improcedente, a polêmica está longe de encerrada, tendo em vista que o Estado brasileiro é réu na Corte Interamericana de Direitos Humanos, acusado de violar normas de direito internacional ao acobertar tais crimes.

Inicialmente, este estudo faz uma contextualização histórica da ditadura e da violência para, em seguida, abordar os fundamentos que sustentam a viabilidade jurídica da responsabilização penal dos autores de crimes do regime militar. Deve-se dizer que a importância do tema não está adstrita às vítimas da ditadura e/ou militares, pois interfere diretamente no modelo de sociedade que se pretende. Trata-se de construir o futuro a partir do passado, justamente para que os erros não se repitam. $O$ assunto é naturalmente polêmico. No epicentro deste imbróglio reside a marca do regime ditatorial que governou o país entre 1964 a 1985: a violência. O

\footnotetext{
${ }^{1}$ DIMOULIS, Dimitri. Justiça de transição e função anistiante no Brasil. Hipostasiações indevidas e caminhos de responsabilização. In: DIMOULIS, Dimitri; MARTINS, Antonio; SWENSSON JUNIOR, Lauro Joppet (Org.). Justiça de Transição no Brasil: Direito, responsabilização e verdade. São Paulo: Saraiva, 2010. p. 98

${ }^{2}$ A reforma das instituições, o direito à reparação das vítimas, o direito à memória e à verdade e o direito à justiça, responsabilizando os autores de crimes contra a humanidade
} 
Estado organizou-se para perseguir opositores, ultrapassando quaisquer limites morais e - principalmente - legais, já que nem mesmo as leis de exceção autorizavam a tortura e a execução extrajudicial. Não fugindo dos fatos, tratou-se aqui de atentar também para a violência. Esta monografia é para além do estudo jurídico um culto à memória. Nas devidas proporções, citando D. Paulo Evaristo Arns, deve-se dizer que estes capítulos retratam uma época tão sombria que nunca deve ser esquecida:

\begin{abstract}
Tocar nos corpos para machucá-los e matar. Tal foi a infeliz, pecaminosa e brutal função de funcionários do Estado em nossa pátria brasileira após o golpe militar de 1964. Tocar nos corpos para destruí-los psicologicamente e humanamente. Tal foi a tarefa ignominiosa de alguns profissionais da Medicina e de grupos militares e paramilitares durante 16 anos em nosso país. Tarefa que acabamos exportando ao Chile, Uruguai e Argentina. Ensinamos outros a destruir e a matar. Lentamente e sem piedade. Sem ética nem humanismo. Macular pessoas e identidades. Perseguir líderes políticos e estudantis. Homens e mulheres, em sua maioria jovens. É destas dores que trata este livro. É desta triste história que nos falam estas páginas marcadas de sangue e dor. ${ }^{3}$
\end{abstract}

Enfim, procurou-se verificar a viabilidade jurídica e, quiçá, política do país acertar as contas com o passado. A partir da análise da ADPF n ${ }^{\circ} 153$ e do Caso Guerrilha do Araguaia x Brasil, em que a Lei de Anistia é confrontada perante os direitos interno e internacional, respectivamente, chega-se à conclusão de que há inúmeras outras dificuldades para além da questão jurídica no tocante às tentativas do povo brasileiro conhecer a própria História. Não bastassem os motivos elencados, o tema estudado é de singular importância também pela sua atualidade: a qualquer momento será apresentada a sentença da Corte Interamericana de Direitos Humanos. Conscientemente, o presente estudo buscou se preparar para o recebimento de tal notícia, antecipando-se a ela e analisando as suas possíveis consequências no direito brasileiro.

\footnotetext{
${ }^{3}$ ARNS, Dom Paulo Evaristo. Prefácio. In: FAMILIARES DE MORTOS E DESAPARECIDOS POLÍTICOS. Dossiê dos Mortos e Desaparecidos a Partir de 1964. São Paulo: Imprensa Oficial do Estado, 1996. p. 449
} 


\section{DITADURA. TORTURA. ANISTIA.}

\subsection{Ditadura.}

\subsubsection{O Golpe de 1964}

O Golpe Militar, concretizado em abril de 1964, foi apenas mais um episódio entre tantas outras intromissões políticas já efetuadas pelas Forças Armadas, cuja origem da longa trajetória intervencionista está em séculos pretéritos. Entretanto, para se compreender o golpe de Estado que instalou a última ditadura do país, não é necessário ir tão longe. Getúlio Vargas deposto em 1945 e vencedor das eleições presidenciais de 1950 encontrava-se novamente ameaçado por militares alinhados aos interesses norte-americanos, insatisfeitos com sua política nacionalista. Em agosto de 1954, no auge da crise que enfrentava, Vargas suicidou-se com um tiro no peito. Seu gesto dramático não só impediu o iminente golpe como conseguiu adiá-lo por quase dez anos. A conspiração aguardaria um momento mais favorável para a tomada do poder, pois estava receosa com a comoção popular desencadeada pela trágica morte do líder nacional. Nascia ali o golpe de 1964.

Juscelino Kubitschek assumiu em 1956 e governou até 1961 com relativa estabilidade política. Quem o sucedeu foi Jânio Quadros, figura controversa que veio a renunciar em 25 de agosto de 1961 alegando "forças ocultas" não totalmente esclarecidas pelos historiadores. ${ }^{4} \mathrm{O}$ vice-presidente era João Goulart ${ }^{5}$, considerado uma ameaça esquerdista pela cúpula das Forças Armadas. Os Ministros militares não aceitaram a posse de Jango,

\footnotetext{
4 ARQUIDIOCESE DE SÃO PAULO. Brasil: nunca mais: um relato para a História. $15^{\mathrm{a}}$ ed.. Petrópolis: Vozes, 1986. p. 57

${ }^{5}$ Presidente e vice-presidente não integravam a mesma chapa. Eram, respectivamente, o primeiro e o segundo colocados nas eleições presidenciais.
} 
como era conhecido, gerando forte mobilização social em sua defesa - com destaque para o estado do Rio Grande do Sul, cujo governador era Leonel Brizola, seu cunhado. Os militares vislumbraram a guerra civil que se ensaiava: em recuo estratégico, a posse do vice-presidente foi condicionada à adoção do sistema parlamentarista, restringindo-lhe significativamente o poder. Uma esmagadora vitória em um plebiscito, realizado em janeiro de 1953, devolveu a João Goulart os poderes presidenciais e derrubou o parlamentarismo imposto pelos militares. Seu mandato foi marcado pela radicalização do discurso nacionalista, limitando as remessas de lucros obtidos no país para o exterior, e em defesa das reformas de base, especialmente a agrária. As terras improdutivas seriam divididas entre trabalhadores rurais despossuídos e os lucros das empresas transnacionais reinvestidos no país, entre outras coisas. Os movimentos sociais se mobilizaram, crescendo a expectativa de que viriam as reformas estruturais tão esperadas pela sociedade. Logicamente, tais medidas ameaçaram diretamente os interesses dos latifundiários, dos grandes grupos econômicos e da classe-média conservadora, que não via com bons olhos as mudanças anunciadas. Havia uma crescente polarização entre reformistas e conservadores, enquanto as Forças Armadas já conspiravam contra uma suposta "ameaça comunista" que pairava sob o governo. No auge desta radicalização, em 13 de março de 1964, no Rio de Janeiro, durante o histórico Comício da Central, Jango fez um inflamado discurso em defesa de seu governo e alimentou ainda mais o clima de instabilidade política. "Assinou dois decretos. Um desapropriava as terras ociosas das margens das rodovias e açudes federais. Outro encampava as refinarias particulares de petróleo." ${ }^{6}$ Tentou, com o comício, demonstrar a legitimidade das medidas anunciadas e frear o golpe em andamento.

\footnotetext{
${ }^{6}$ GASPARI, Elio. A ditadura envergonhada. São Paulo: Companhia das Letras, 2002. p. 48
} 
"O conservadorismo paulista respondera ao comício do dia 13 com uma Marcha da Família com Deus pela Liberdade em que se reuniram perto de 200 mil pessoas com faixas ameaçadoras" "que chegavam a sugerir a deposição do Presidente João Goulart. As bases para o golpe de Estado estavam estruturadas. É sabido, aliás, que o governo estadunidense estava diretamente envolvido nas articulações, preparado inclusive para intervir no Brasil, se necessário fosse. ${ }^{8} \mathrm{O}$ estopim foi uma revolta de marinheiros e fuzileiros navais, ocorrida no final de março, em que o Jango teria sido complacente com os rebeldes. Assim, sob o argumento de uma iminente guinada socialista por parte do governo, as Forças Armadas, apoiadas por empresários, latifundiários, interesses externos, boa parte da classe média e da Igreja Católica, depuseram João Goulart no dia $1^{\circ}$ de abril de 1964, praticamente sem resistência. Tratou-se de um golpe cívico-militar, com bases sólidas na burguesia conservadora. "Era evidente que todo aquele movimento nacionalista e popular, estruturado em bases essencialmente legais, não tinha condições de enfrentar a força das armas." ${ }^{9}$ Para que se compreenda a exata dimensão deste apoio, são de extremo valor as palavras do jornalista Roberto Marinho, publicadas no editorial $O$ Julgamento da Revolução, na capa do jornal $O$ Globo, dia 7 de outubro 1984:

PARTICIPAMOS da Revolução de 1964, identificados com os anseios nacionais de preservação das instituições democráticas, ameaçadas pela radicalização ideológica, greves, desordem social e corrupção generalizada. [...]

TEMOS permanecido fiéis aos seus objetivos [...]

NÃO HÁ memória de que aja ocorrido aqui, ou em qualquer outro país, que um regime de força, consolidado há mais de dez anos, se tenha utilizado do seu próprio arbítrio para se auto-limitar, extinguindo os poderes de exceção, anistiando adversários, em plena liberdade de imprensa. É esse, indubitavelmente, o maior feito da Revolução de $1964 .{ }^{10}$

\footnotetext{
${ }^{7}$ GASPARI, Elio. A ditadura envergonhada. p. 48-49

${ }^{8}$ GASPARI, Elio. A ditadura envergonhada. p. 101

${ }^{9}$ GASPARI, Elio. A ditadura envergonhada. p. 59

${ }^{10}$ MARINHO, Roberto. O Julgamento da Revolução. O Globo, Rio de Janeiro, p.1, 7 out. 1984.
} 
Por ora, cabe apenas registrar a divergência em relação aos conceitos de "instituições democráticas" e de "liberdade de imprensa" empregados.

\subsubsection{A ditadura militar}

Costuma-se dividir o regime militar em três fases. A primeira delas, iniciada com o Golpe de 1964, durou até 13 de dezembro de 1968, quando é baixado o Ato Institucional $n^{\circ} 5$. A partir desta data, começa o período mais cruel de toda a repressão política: os chamados "anos de chumbo", que vão até a posse de Ernesto Geisel, em 1974, quando uma lenta abertura política contrasta com um aumento dos desaparecimentos forçados. Esta terceira fase é caracterizada pela transição para a democracia, arrastando-se até o fim da ditadura.

O regime nasceu violento por excelência. Basta lembrar a tortura pública de Gregório Bezerra, histórico militante do PCB, aos 64 anos de idade, logo no dia posterior ao golpe:

No dia 2 de abril, no Recife, o dirigente comunista Gregório Bezerra foi amarrado seminu à traseira de um jipe e puxado pelos bairros populares da cidade. No fim da viagem, foi espancado por um oficial do Exército, com uma barra de ferro, em praça pública. Machucado e sentado no chão do pátio do quartel da Companhia de Motomecanização no bairro da Casa Forte, Gregório Bezerra foi visto na noite de 2 de abril pelos espectadores da TV Jornal do Commercio, que o filmara. Episódios semelhantes repetiram-se em algumas cidades do país. ${ }^{11}$

Inicialmente, prevaleceu nas Forças Armadas o projeto de oficiais da Escola Superior de Guerra (ESG), representada na pessoa do PresidenteMarechal Castello Branco. A "doutrina da segurança nacional” buscava justificar a limitação dos direitos fundamentais lastreada na dogmática da ideologia anticomunista. Identificava os "inimigos da pátria" dentro do próprio povo, de modo que as garantias constitucionais deveriam ceder em

${ }^{11}$ GASPARI, Elio. A ditadura envergonhada. p. 132 
benefício da segurança nacional. Nesta lógica, em 9 de abril de 1964, é editado o primeiro Ato Institucional: a ditadura, entre outras coisas, cassa mandatos, suspende direitos políticos, expurga militares, intervém em sindicatos e efetua prisões. ${ }^{12}$ Era mais um largo passo na missão de perseguir os movimentos populares. Não bastando derrubar um governo constitucionalmente eleito e revogar os atos a favor da reforma agrária e da remessa de lucros para o exterior, o Estado se especializou em exterminar suas inimizades.

O segundo Ato Institucional, editado em outubro de 1965, fulmina os "partidos políticos e permite ao Executivo fechar o Congresso Nacional quando bem entender, torna indiretas as eleições para presidente da República e estende aos civis a abrangência da Justiça Militar." ${ }^{13}$ Passam a existir legalmente apenas dois partidos: a ARENA (Aliança Renovadora Nacional), governista, e o MDB (Movimento Democrático Brasileiro), que poderia fazer uma oposição moderada. Eleições indiretas para Governador foram instituídas por meio do Ato Institucional $\mathrm{n}^{\circ} 3 . \mathrm{O}$ regime se aparelhava juridicamente para a escalada de violência: em 1967, após a posse do Presidente Costa e Silva, outorgaram-se uma nova Constituição, uma nova Lei de Segurança Nacional e uma Lei de Imprensa. Na sexta-feira 13 de dezembro de 1968, é editado o nefasto Ato Institucional $\mathrm{n}^{\circ}$ 5. Este veio suspender o habeas corpus para crimes políticos e possibilitar ao "Presidente da República, ouvido o Conselho de Segurança Nacional, e sem as limitações previstas na Constituição, [...] suspender os direitos políticos de quaisquer cidadãos pelo prazo de 10 anos e cassar mandatos eletivos" ${ }^{, 14}$, excluindo de apreciação do poder judiciário todos os atos praticados em sua decorrência. Em suma: não há mais limites legais para a perseguição política.

\footnotetext{
${ }^{12}$ GASPARI, Elio. A ditadura envergonhada. p. 21-22

${ }^{13}$ ARQUIDIOCESE DE SÃO PAULO. Brasil: nunca mais. p. 61

${ }^{14}$ Art. $4^{\circ}$, caput, do Ato Institucional n ${ }^{\text {a }}$ 5, de 13 de dezembro de 1968.
} 
Escancarada, a ditadura firmou-se. A tortura foi o seu instrumento extremo de coerção e o extermínio, o último recurso da repressão política que o Ato Institucional $\mathrm{n}^{\circ} 5$ libertou das amarras da legalidade. A ditadura envergonhada foi substituída por um regime a um só tempo anárquico nos quartéis e violento nas prisões. Foram os Anos de Chumbo. ${ }^{15}$

$\mathrm{O}$ endurecimento da ditadura militar, dialeticamente, provocou a radicalização da resistência. É verdade que as ações da guerrilha urbana já haviam iniciado antes do AI-5, entretanto, é com ele que a luta armada passa a ser uma epidemia entre os núcleos da esquerda, culminando no sequestro do embaixador estadunidense Charles Burke Elbrick, em setembro de 1969. O AI-5 joga todos na clandestinidade; não há mais outra forma de contestar o regime que não pelas armas. Note-se aqui que a violência praticada pela ditadura e pelos perseguidos políticos encontram-se em planos distintos. Enquanto os últimos agiam em resistência a um Estado ilegítimo, os primeiros derrubaram o poder eleito constitucionalmente pelo voto popular e instituíram uma ditadura assassina de seus opositores. Manifestar-se pacificamente contra ela implicava ser submetido a torturas e/ou assassinatos - como tantos e tantos foram -, de sorte que, para os que não aceitaram a submissão, as armas surgiram como meio de defesa da própria vida - ou não - perante os potenciais martírios do porão. O poder fora assaltado e o novo regime torturava e matava quem a ele se opunha, em nome de uma suposta segurança nacional. "Consequentemente, era lícito lutar contra o establishment"16.

Em homenagem à verdade, deve-se reconhecer que a ditadura militar foi extremamente eficiente no seu projeto de repressão política. A tortura praticada unicamente pelo Estado - estraçalhou a resistência, viabilizando a abertura do regime. A ditadura militar foi caracterizada justamente pelo uso

\footnotetext{
${ }^{15}$ GASPARI, Elio. A ditadura escancarada. São Paulo: Companhia das Letras, 2002. p. 13

${ }^{16}$ STRECK, Lenio. A Lei de Anistia, a Constituição e os Direitos Humanos no Brasil: Lenio Streck Responde. Revista anistia política e justiça de transição: Ministério da Justiça. Brasília, n. 2, p. 28, jul./dez. 2009.
} 
indiscriminado e desproporcional da violência contra todos que pudessem ameaçar a "segurança nacional". A resistência, em verdade, não estava preparada para o combate prolongado contra um inimigo tão duro: a tortura.

\subsection{Tortura.}

Sei que assim falando pensas Que esse desespero é moda em 73 E eu quero é que esse canto torto Feito faca corte a carne de vocês

A palo seco, Belchior

"O que torna a tortura atraente é o fato de que ela funciona. O preso não quer falar, apanha e fala. É sobre essa simples constatação que se edifica a complexa justificativa da tortura pela funcionalidade." ${ }^{17}$ A ditadura militar institucionalizou esta prática; era a regra de conduta na luta contra a subversão, avalizada pelas mais altas patentes. ${ }^{18}$ Sobre a utilização sistemática da tortura pelo regime, muito mais vale transcrever as palavras da professora Cecília Coimbra, militante e Presidente do grupo Tortura Nunca Mais/RJ:

A tortura - que, ao longo de todo século XX, foi cotidianamente utilizada contra os "desclassificados" sociais - especialmente a partir do AI-5 (13/12/1968), passou a ser também aplicada aos opositores políticos da ditadura militar.

Apesar da implantação em 1964 de um governo de força, somente a partir do AI5 é que a tortura se tornou uma política oficial de Estado. A vitória da chamada "linha dura", o golpe dentro do golpe instituíram o terrorismo de Estado que utilizou sistematicamente o silenciamento e o extermínio de qualquer oposição ao regime. O AI-5 inaugurou também o governo Médici (1969-1974), período em que mais se torturou em nosso país. ${ }^{19}$

\footnotetext{
${ }^{17}$ GASPARI, Elio. A ditadura escancarada. p. 37

${ }^{18}$ GASPARI, Elio. A ditadura escancarada. p. 24; 31; 37; 43; 186

${ }^{19}$ COIMBRA, Cecília Maria Bouças. Práticas psi e Tortura no Brasil. Revista Psicologia Política. São Paulo: SBPP, v.1, n. 2, p. 97, jul./dez. 2001.
} 
Ilustrativamente, vale lançar os olhos no tipo penal do crime de tortura, trazido pela lei $\mathrm{n}^{\circ} 9.455$, de 7 de abril de 1997 :

Art. $1^{\circ}$ Constitui crime de tortura:

I - constranger alguém com emprego de violência ou grave ameaça, causando-lhe sofrimento físico ou mental:

a) com o fim de obter informação, declaração ou confissão da vítima ou de terceira pessoa;

b) para provocar ação ou omissão de natureza criminosa;

c) em razão de discriminação racial ou religiosa;

II - submeter alguém, sob sua guarda, poder ou autoridade, com emprego de violência ou grave ameaça, a intenso sofrimento físico ou mental, como forma de aplicar castigo pessoal ou medida de caráter preventivo. ${ }^{20}$

José Afonso da Silva, conceitualmente, assim a define:

Trata-se de um conjunto de procedimentos destinado a forçar, com todos os tipos de coerção física e moral, a vontade de um imputado ou outro sujeito, para admitir, mediante confissão ou depoimento, assim extorquidos, a verdade da acusação. [...] Pior ainda se apresenta a tortura quando usada como forma de obtenção, depoimento ou de dedo-durismo nos chamados crimes políticos, já que estes mesmos são, no mais das vezes, forjados em satisfação do autoritarismo. ${ }^{2}$

Em verdade, a teoria não é suficiente para que se experimente a sua intragável natureza, "porque a tortura é o crime mais cruel e bárbaro contra a pessoa humana." 22 A tortura é a antítese da dignidade humana; enquanto um preso era - ou é - torturado, toda a humanidade estava - ou está - sendo atingida. Faz-se necessário voltar aos porões. É preciso lembrar o suplício do "pau-de-arara", do choque elétrico, do afogamento, do abuso sexual, da "cadeira do dragão", da "geladeira" e de tantos outros métodos utilizados pelo Estado brasileiro contra os seus próprios filhos. Estes dolorosos fatos representam a fonte das polêmicas sobre a tortura e a anistia. Esquecendoos, a discussão torna-se superficial e estéril, justamente por desprezar a

\footnotetext{
${ }^{20}$ Lei $n^{\circ}$ 9.455, de 7 de abril de 1997, inspirada na Convenção Contra a Tortura e Outros Tratamentos ou Penas Cruéis, Desumanos ou Degradantes, da ONU

${ }^{21}$ SILVA, José Afonso da. Curso de Direito Constitucional Positivo. $27^{\mathrm{a}}$ ed.. São Paulo: Malheiros, 2006. p. 203-205.

${ }^{22}$ POTTER, Philip. Prefácio. In: ARQUIDIOCESE DE SÃO PAULO. Brasil: nunca mais: um relato para a História. $15^{\text {a }}$ ed.. Petrópolis: Vozes, 1986. p. 17
} 
realidade nas suas mais trágicas proporções. Em verdade, arredondando por baixo, "acredita-se hoje que cerca de cinqüenta mil pessoas tiveram de passar pelos porões da ditadura e, destas, não menos de vinte mil tiveram de ser submetidas à tortura." ${ }^{, 23} \mathrm{O}$ procedimento padrão era deixar o torturado nu e pendurá-lo no "pau-de-arara", alternando choques elétricos, espancamentos e afogamentos:

(...) O pau-de-arara consiste numa barra de ferro que é atravessada entre os punhos amarrados e a dobra do joelho, sendo o "conjunto" colocado entre duas mesas, ficando o corpo do torturado pendurado a cerca de 20 ou $30 \mathrm{~cm}$. do solo. Este método quase nunca é utilizado isoladamente, seus "complementos" normais são eletrochoques, a palmatória e o afogamento. (...)

$[\ldots]$

(...) O eletrochoque é dado por um telefone de campanha do Exército que possuía dois fios longos que são ligados ao corpo, normalmente nas partes sexuais, além dos ouvidos, dentes, língua e dedos. (...)

(...) que foi conduzido às dependências do DOI-CODI, onde foi torturado nu, após tomar banho pendurado no pau-de-arara, onde recebeu choques elétricos, através de um magneto, em seus órgãos genitais e por todo o corpo, (...) foi-lhe amarrado um dos terminais do magneto num dedo de seu pé e no seu pênis, onde recebeu descargas sucessivas, a ponto de cair no chão, $(\ldots)^{24}$

Contudo, a violência não se limitava aos métodos convencionais, variando ao sabor da perversão e da criatividade do torturador. Há relatos de utilização de animais, como cobras e baratas, nas sessões de sadismo:

(...) que foi transferida para o DOI da P. Ex. da B. Mesquita, onde foi submetida a torturas com choque, drogas, sevícias sexuais, exposição de cobras e baratas; que essas torturas eram efetuadas pelos próprios Oficiais; (...)

(...) a interrogada quer ainda declarar que durante a primeira fase do interrogatório foram colocadas baratas sobre o seu corpo, e introduzida uma no seu ânus. $(\ldots)^{25}$

Mais do que obter determinada informação, a tortura tem por finalidade a destruição da dignidade do outro, subjugando-lhe o próprio espírito à vontade do seu carrasco. Este, por sua vez, alimenta-se do

\footnotetext{
${ }^{23}$ SWENSSON JUNIOR, Lauro Joppert. Anistia Penal: Problemas de Validade Da Lei de Anistia Brasileira (Lei 6.683/79). Curitiba: Juruá, 2007. p. 38

${ }^{24}$ ARQUIDIOCESE DE SÃO PAULO. Brasil: nunca mais. p. 34-35

${ }^{25}$ ARQUIDIOCESE DE SÃO PAULO. Brasil: nunca mais. p. 39
} 
sofrimento e se excita com o macabro ritual que promove. $\mathrm{O}$ indivíduo torturado tem a humanidade subtraída; deixa de ser gente para ser menos do que coisa. As sessões de tortura não se explicavam somente pelo escopo investigativo, eram cerimônias de culto aos prazeres mais perversos que um ser humano pode trazer consigo. Prazeres tão perversos quanto humanos, diga-se de passagem, já que nem mesmo os animais podem tê-los, de tão demoníacos que são. Veja-se:

\begin{abstract}
"O preso só lastima uma coisa: o 'diabo' do corpo continua agüentando", lembraria o dirigente comunista Marco Antônio Coelho. Ainda que a certa altura a mente prefira a morte à confissão, aquele corpo dolorido se mantém vivo, permitindo o suplício. A dor destrói o mundo do torturado ao mesmo tempo que lhe mostra outro, o do torturador, no qual não há sofrimento, mas o poder de criálo. Quando a vítima se submete, conclui-se um processo em que a confissão é um aspecto irrelevante. O preso, na sala de suplícios, troca seu mundo pelo do torturador. "A vítima faz mais do que dar uma informação ao carrasco, ela passa a reconhecer nele o senhor da sua voz, ou seja, de sua humanidade", ensina o professor Pierre Vidal-Naquet.

[...] Oficiais do DOI do Rio atendiam ao telefone em nome da "Funerária Boa Morte", e nele um torturador disse a uma jovem, durante uma Sexta-Feira Santa, que sofreria como Jesus Cristo. Em São Paulo, o agente Campão (cáften da bocado-lixo) informava: "Meu nome é Lúcifer". Um torturador disse no Ceará: “Aqui não é o exército, nem a marinha, nem aeronáutica. Aqui é o inferno". Na PE da Vila Militar, um sargento mostrava a cancela do quartel e dizia: "Dali pra dentro Deus não entra. Se entrar, a gente dependura no pau-de-arara". ${ }^{26}$
\end{abstract}

Muitos seres humanos morreram em decorrência das torturas, outros enlouqueceram. Dos que sobreviveram, todos levaram consigo os traumas físicos e/ou mentais produzidos nos porões. Em razão de gravíssimas sequelas psicológicas, alguns vieram a se suicidar no exílio, como os casos de frei Tito de Alencar Lima e Maria Auxiliadora Lara Barcellos. O primeiro, barbaramente torturado de diferentes formas e por várias equipes de "interrogadores" - inclusive pelo Delegado do DOPS Sergio Fleury, o mais notório torturador do regime -, passou a sentir-se constantemente perseguido: "ele ouvia permanentemente a voz do comissário Fleury, seu torcionário, que lhe ordena que se renda enfim e confesse, do contrário cada

\footnotetext{
${ }^{26}$ ARQUIDIOCESE DE SÃO PAULO. Brasil: nunca mais. p. 41
} 
um dos membros da sua família será torturado."27 Enforcou-se na França, em 1974. Maria Auxiliadora, a Dora, foi torturada coletivamente com Chael Charles Schreier - morto durante o suplício - e Antônio Roberto Espinoza. Além de sofrer várias sevícias sexuais por parte de seus carrascos, estes obrigaram Chael e Antônio a praticar atos como beijar o seu corpo enquanto "o cabo Nilson Pereira insistia para que [...] o fitasse, sem o qual não lhe entregaria a refeição". ${ }^{28}$ Foi deixada nua por sete meses ${ }^{29}$; experimentou as mais intensas dores. Segundo ela, quando no exílio: "Foram intermináveis dias de Sodoma. Me pisaram, cuspiram, me despedaçaram em mil cacos. Me violentaram nos meus cantos mais íntimos. Foi um tempo sem sorrisos. Um tempo de esgares, de gritos sufocados"30. Banida, na Alemanha Ocidental "Dora tivera uma pane psíquica."31 Pesadelos constantes a atormentavam e oprimiam. Em 1976, jogou-se embaixo de um trem, engrossando a lista de vítimas fatais da ditadura militar.

Merece destaque a crueldade com que a repressão tratou as mulheres, atingidas especialmente por este triste fenômeno. $\mathrm{Na}$ lógica de destruir a essência daqueles seres humanos, a sexualidade feminina foi um elemento fundamental a ser explorado. Lembrem-se mais dois casos:

A engenheira Elsa Maria Pereira Lianza, de 25 anos, presa no Rio, narrou em seu depoimento, em 1977:

(...) que a interrogada foi submetida a choques elétricos em vários lugares do corpo, inclusive nos braços, nas pernas e na vagina; que o marido da interrogada teve a oportunidade de presenciar essas cenas relacionadas com choques elétricos e os torturadores amplificavam os gritos da interrogada, para que os mesmos fossem ouvidos pelo seu marido; (...)

A bancária Inês Etienne Romeu, de 29 anos, denunciou:

\footnotetext{
${ }^{27}$ PLASSAT, Frei Xavier. A tortura e a morte de Tito. In: CAVALCANTI, Pedro Celso Uchoa; RAMOS, Jovelino (Org.). Memórias do exílio: Brasil 1964-19??. Lisboa: Arcádia, 1976. p. 359

${ }^{28}$ ARQUIDIOCESE DE SÃO PAULO. Brasil: nunca mais. p. 48

${ }^{29}$ GUARANY, Reinaldo. A fuga. São Paulo: Brasiliense, 1984. p. 113

${ }^{30}$ BARCELLOS, Maria Auxiliadora Lara. Continuo sonhando. In: CAVALCANTI, Pedro Celso Uchoa; RAMOS, Jovelino (Org.). Memórias do exílio: Brasil 1964-19??. Lisboa: Arcádia, 1976. p. 317

${ }^{31}$ GUARANY, Reinaldo. A fuga. p. 141
} 
(...) A qualquer hora do dia ou da noite sofria agressões físicas e morais. "Márcio" invadia minha cela para "examinar" meu ânus e verificar se "Camarão" havia praticado sodomia comigo. Este mesmo "Márcio" obrigou-me a segurar seu pênis, enquanto se contorcia obscenamente. Durante este período fui estuprada duas vezes por "Camarão" e era obrigada a limpar a cozinha completamente nua, ouvindo gracejos e obscenidade, os mais grosseiros. $(. . .)^{32}$

No Rio de Janeiro, após ser levado para o $1^{\circ}$ Batalhão de Polícia do Exército, na Rua Barão de Mesquita, no bairro da Tijuca, "Mário Alves ficou oito horas na Sala Roxa. [...] Sangrava pelo nariz. Tinha sido empalado com um cassetete." ${ }^{33}$ Seu corpo não aguentou e encontra-se desaparecido até o nascimento destas linhas. Infelizmente, os relatos acima são casos pinçados entre uma avalanche de outros tantos, análogos. Tudo executado pelo Estado, em suas dependências. Estupravam-se mulheres na frente dos maridos, mulheres grávidas eram torturadas até o aborto, filhos eram levados ao encontro dos pais torturados. É impossível listar todas as atrocidades praticadas em nome da famigerada segurança nacional. Uma descrição genérica do cotidiano dos porões pode ser encontrada no auto de qualificação e interrogatório de José Milton Ferreira de Almeida, ouvido em São Paulo, no ano de 1976:

(...) que, pior do que tudo isso, foi passar dias inteiros, por vários dias, vendo e ouvindo várias pessoas serem torturadas, crucificadas, penduradas nos registros das celas, espancadas nos corredores, gritando numa agonia indescritível; que viu pais e filhos sendo torturados, esposos e esposas serem também torturados e um sendo obrigado a torturar o outro; que viu velhos de 70 anos serem praticamente espancados e chegarem ao ponto de debilitamento total; que essas coisas que diz agora são uma síntese de que viveu; $(\ldots)^{34}$

Os porões foram legalizados; fazia-se o que se queria neles. A tortura era praticada em todos eles. No dia 8 de outubro de 1969, em um quartel da Vila Militar no Rio de Janeiro, foi ministrada uma aula prática de tortura para um número de quase cem pessoas. Conforme as informações e técnicas

\footnotetext{
${ }^{32}$ ARQUIDIOCESE DE SÃO PAULO. Brasil: nunca mais. p. 46-47

${ }^{33}$ GASPARI, Elio. A ditadura escancarada. p. 171

${ }^{34}$ ARQUIDIOCESE DE SÃO PAULO. Brasil: nunca mais. p. 206
} 
iam sendo projetadas nos slides, os "professores" desenvolviam na carne de presos políticos a metodologia do sofrimento. Tais denúncias fazem parte de depoimentos prestados por testemunhas e torturados ${ }^{35}$, sendo os fatos narrados pelo jornalista Elio Gaspari, em A Ditadura Envergonhada:

Os presos foram enfileirados perto do palco, e o "tenente Ailton" identificou-os para os convidados. Tinha três sargentos por acólitos. Com a ajuda de slides, mostrou desenhos de diversas modalidades de tortura. Em seguida os presos tiveram de ficar só de cuecas.

Maurício Vieira de Paiva, 24 anos, quintanista de engenharia, foi ligado a um magneto pelos dedos mínimos das mãos. Era a máquina de choques elétricos. Depois de algumas descargas, o tenente-mestre ensinou que se devem dosar as voltagens de acordo com a duração dos choques. Chegou a recitar algumas relações numéricas, lembrando que o objetivo do interrogador é obter informações e não matar o preso.

Murilo Pinto da Silva, 22 anos, funcionário público, ficou de pés descalços sobre as bordas de duas latas abertas. Pedro Paulo Bretas, 24 anos, terceiranista de medicina, foi submetido ao esmagamento dos dedos com barras de metal. Outro preso, um ex-soldado da Polícia Militar, apanhou de palmatória nas mãos e na planta dos pés. "A palmatória é um instrumento com o qual se pode bater num homem horas a fio, com toda a força", explicou o tenente.

No pau-de-arara penduraram Zezinho, que estava na PE por conta de crimes militares. Ailton explicou - enquanto os soldados demonstravam - que essa modalidade de tortura ganhava eficácia quando associada a golpes de palmatória ou aplicações de choques elétricos, cuja intensidade aumenta se a pessoa está molhada.

"Começa a fazer efeito quando o preso já não consegue manter o pescoço firme e imóvel. Quando o pescoço dobra, é que o preso está sofrendo", ensinou o tenente-professor.

O Exército brasileiro tinha aprendido a torturar. ${ }^{36}$

\subsection{Anistia.}

A resistência sucumbiu na luta contra a tortura. As "quedas" dos militantes eram sucessivas. Quem resistira estava morto, preso ou exilado. $\mathrm{O}$ trabalho fora concluído. A esquerda estava esmagada, afastando de vez a "ameaça comunista" que justificara o regime. Ernesto Geisel toma posse como Presidente em 1974 e anuncia uma lenta abertura política. Em verdade, aumentam os desaparecimentos forçados. Enquanto o governo

\footnotetext{
${ }^{35}$ ARQUIDIOCESE DE SÃO PAULO. Brasil: nunca mais. p. 31-32

${ }^{36}$ GASPARI, Elio. A ditadura envergonhada. p. 361-362
} 
planejava a tal abertura, eliminava fisicamente os últimos focos de resistência interna. Em resposta, crescia no seio da sociedade civil o movimento pela anistia: em 1975, surge em São Paulo o Movimento Feminino pela Anistia, configurado pela militância de familiares em favor dos direitos de seus parentes perseguidos. Paralelamente, nos porões, o jornalista Vladimir Herzog e o metalúrgico Manuel Fiel Filho são assassinados mediante tortura, deflagrando novos protestos. Assim, a luta pela anistia nasce vinculada à defesa dos direitos humanos e à cessação de todas as violações que continuavam a amaldiçoar o país. O movimento cresce e, no fim da década de 70, muitas outras vozes já clamam em coro por anistia, entre elas a da Igreja Católica. Fala-se agora em "anistia ampla, geral e irrestrita". Mas, para quem?

Em nenhum momento do movimento popular cogitou-se a anistia bilateral, ou seja, que beneficiasse também os torturadores. A luta foi em prol das vítimas do regime militar, uma vez que tantos brasileiros estavam exilados ou cumprindo pena por resistir à ditadura. Ser "ampla, geral e irrestrita" significava beneficiar todos os perseguidos pela repressão, sem fazer distinção pelo tamanho da pena aplicada, pelo número de condenações ou por qualquer outro critério. A reivindicação era clara: anistia para os presos políticos, contemplando todos que foram afetados pelos atos de exceção. "D. Paulo Evaristo Arns, cardeal-arcebispo de São Paulo, por exemplo, desde 1975 que reclamava 'anistia generosa para os presos políticos de nossa terra'. ${ }^{37}$ Para que se exponha com mais clareza o que se pretende, é importante transcrever uma passagem do livro Anistia ontem e hoje, de Roberto Ribeiro Martins, publicado pela primeira vez em 1978:

Para quem, afinal, uma anistia ampla e irrestrita? Quem são "os que precisam, desta anistia por que tanto se luta?

Se por um lado é justo - para simplificar, objetivar e nomear os mais necessitados - dizer "anistia para todos os presos, banidos, exilados e cassados políticos", por

\footnotetext{
${ }^{37}$ MARTINS, Roberto Ribeiro. Anistia ontem e hoje. $3^{\text {a }}$ ed. São Paulo: Brasiliense, 2010. p. 167
} 
outro não se resume nessas as categorias de brasileiros atingidos pelos atos e leis de exceção, candidatos ao benefício da anistia por vir. Precisar todas as categorias é necessário, não só para se ter um real dimensionamento do problema, como para servir de subsidio até para o legislador na hora em que se deparar com ele: nenhum dos punidos ou perseguidos políticos deve ser excluído dos benefícios. Só assim a anistia será geral, ampla. ${ }^{38}$

A anistia política protestada pela sociedade civil organizada não beneficiava os crimes da ditadura. Aliás, o movimento pela anistia exigiu, inclusive, a responsabilização criminal dos agentes do Estado torturador. Recorrendo novamente aos registros da época, verifica-se que, em maio de 1979, assim se manifestou o Comitê Brasileiro pela Anistia - RJ:

Com o crescimento do Movimento pela Anistia ampla, geral e irrestrita em escala nacional e sobretudo a partir da realização do Congresso Nacional pela Anistia, a luta pela elucidação da situação dos desaparecidos transcendeu o âmbito dos esforços dos familiares e converteu-se numa campanha nacional, coordenada por uma Comissão Nacional pelos Mortos e Desaparecidos criada pelos movimentos de Anistia. E nessa campanha nacional pelos desaparecidos e mortos estão definidos os seguintes objetivos:

- Exigir esclarecimentos ao governo sobre os desaparecimentos;

- Exigir que sejam apuradas as responsabilidades de tais desaparecimentos e mortes;

- Encetar uma campanha específica pelos mortos do Araguaia, para saber onde estão os corpos e a relação de nomes dos mortos. ${ }^{39}$

Diante do contexto, em 1979 o governo achou apropriado conceder a tão pedida anistia. Na realidade, a medida já não ameaçava mais, vez que as grandes lideranças da resistência estavam mortas e/ou desaparecidas. Por outro lado, era a oportunidade que a repressão tinha para garantir a impunidade dos seus crimes: tratava-se de questão inegociável por parte da ditadura, consciente de sua responsabilidade no terrorismo estatal. O terreno já estava preparado: em 1977, respondendo a um avanço do MDB nas eleições de 1974, foi outorgado o "Pacote de Abril", que, entre outras coisas, instituiu a figura do "Senador biônico". Em 1979, um em cada três

\footnotetext{
${ }^{38}$ MARTINS, Roberto Ribeiro. Anistia ontem e hoje. p. 171

${ }^{39}$ COMITÊ BRASILEIRO PELA ANISTIA - RJ. A Questão dos Desaparecidos. In: CABRAL, Reinaldo; LAPA, Ronaldo (Org.). Desaparecidos Políticos: prisões seqüestros assassinatos. Rio de Janeiro: Comitê Brasileiro pela Anistia, 1979. p. 21
} 
senadores era indicado diretamente pela ditadura. Ao mesmo tempo, cabia exclusivamente ao Presidente da República a iniciativa de qualquer projeto de lei versando sobre anistia. O Presidente Figueiredo, então, elaborou um texto com a redação dúbia, intencionado a anistiar os agentes estatais e a excluir da anistia os militantes de esquerda condenados por crimes violentos. O projeto de lei foi aprovado por 206 votos da ARENA contra 201 votos do MDB, evidenciando a insurgência da oposição contra a proposta que refletia apenas os interesses do Estado autoritário. Sem os "Senadores biônicos", certamente, a Lei de Anistia", publicada em 28 de agosto de 1979 , não teria sido aprovada como foi. ${ }^{41}$

Entretanto, o importante aqui é deixar assentado que a expressão "anistia ampla, geral e irrestrita" não traduz - e também não traduziu durante a luta pela anistia - a idéia de anistia bilateral. Está suficientemente claro que a sociedade não abriu mão de responsabilizar os autores de crimes contra a humanidade. A ditadura, por outro lado, utilizou-se de um projeto de lei de iniciativa de um Presidente militar, submetido a um Congresso Nacional sem qualquer liberdade política, para deixar sem investigação os crimes por ela cometidos. Sobre a luta pela e por qual anistia, volte-se ao livro Anistia ontem e hoje:

O que se trata é de anistiar as vítimas dos atos e leis de exceção. Os que foram punidos de uma ou outra forma. Os crimes porventura praticados no exercício de função policial não foram ainda plenamente desvendados, e muito menos punidos. Este é um problema diverso daquele da anistia e, como tal, deve ser tratado e resolvido separadamente dela, ressalvados os direitos de justiça de quem quer que seja. Não há, pois, como confundir.

É preciso ainda ressaltar que os que têm se pronunciado partidários de uma "anistia recíproca" antes acrescentam "ampla e irrestrita", situando-se entre aqueles que a entendem no essencial de forma correta. [...]

Assim, é preciso separar as coisas: anistia de direitos humanos desrespeitados. $\mathrm{O}$ que é natural e justo é que, no futuro, aqueles que achem que tiveram

\footnotetext{
${ }^{40}$ Lei $\mathrm{n}^{\mathrm{o}} 6.683$, de 28 de agosto de 1979.

41 ZELIC, Marcelo. A auto-anistia e a farsa de um acordo nacional. Disponível em $<$ http://www.torturanuncamais-rj.org.br/artigos.asp?Codartigo $=83 \&$ ecg $=0>$. Acesso em 4 set. 2010 .
} 
desrespeitados os seus mínimos direitos humanos reclamem um esclarecimento de tudo. ${ }^{42}$

Reforçando o afirmado, tragam-se para hoje as palavras do poeta Alex Polari de Alverga - que presenciou de sua cela, em 1971, a morte sob tortura de Stuart Angel Jones, filho da estilista Zuzu Angel - sobre a luta pela anistia, quando ainda preso, em janeiro de 1979:

Daí a necessidade de colocar o problema da extirpação da LSN, dos tribunais militares, da tortura, do desmantelamento dos órgãos de segurança, da responsabilidade penal daqueles que assassinaram opositores em nome da segurança do Estado. Daí a necessidade de globalizar todas essas questões na luta pela Anistia Ampla, Geral e Irrestrita.

No caso do assassinato de Stuart, presenciado por mim de maneira direta e outras pessoas de forma indireta, amplamente documentado e divulgado no Brasil e exterior, é no mínimo estranho que nenhuma providência tenha sido tomada, nenhuma averiguação ou acareação tenha sido feita pela Justiça. Não tenho dúvidas que tal só se dará em outro momento, quando essa página negra da nossa História for definitivamente fechada. Por enquanto ainda é questão de honra para quem está no poder o silêncio sobre tais casos, pois disso depende inclusive a própria sobrevivência desse mesmo poder que continua sendo o mesmo. Acredito que mais dia menos dia a força do movimento popular será forte para julgar tais crimes. $^{43}$

${ }^{42}$ MARTINS, Roberto Ribeiro. Anistia ontem e hoje. p. 214

${ }^{43}$ ALVERGA, Alex Polari. Novas reflexões de Alex Polari sobre Stuart. In: CABRAL, Reinaldo; LAPA, Ronaldo (Org.). Desaparecidos Políticos: prisões seqüestros assassinatos. Rio de Janeiro: Comitê Brasileiro pela Anistia, 1979. p. 119 


\section{A ADPF № 153}

\subsection{Dos fundamentos da inicial}

\subsubsection{Dos crimes conexos}

O fato é que a anistia foi utilizada para deixar impunes os crimes da repressão. Logo, passados quase 30 anos da Lei de Anistia, esta continuava - e ainda continua - envolta de polêmicas acerca de sua interpretação e validade, trazendo para o cenário nacional o dilema já enfrentado por vários países sul-americanos: a legalidade das chamadas autoanistias, outorgadas ainda durante os regimes de exceção. Tanto no Chile quanto no Peru, as respectivas anistias foram invalidadas em razão de decisões da Corte Interamericana de Direitos Humanos, enquanto na Argentina a própria Corte Suprema de Justiça declarou a incompatibilidade das Leis do Ponto Final e da Obediência Devida para com a Convenção Interamericana de Direitos Humanos. No Uruguai, a chamada Lei da Caducidade da Pretensão Punitiva do Estado foi relativizada em determinados casos concretos, sendo também questionada no âmbito do sistema interamericano.

Neste contexto é que, no dia 21 de outubro de 2008, o Conselho Federal da Ordem dos Advogados do Brasil ingressou com uma Arguição de Descumprimento de Preceito Fundamental requerendo ao Supremo Tribunal Federal, mediante uma interpretação conforme a Constituição de 1988, a declaração de que a anistia não beneficiou os crimes contra a humanidade praticados pelos agentes da repressão política durante a ditadura militar no Brasil. Vários foram os argumentos invocados para sustentar o pedido, desde a invalidade da lei quanto a sua recepção condicionada a uma determinada interpretação. Segundo a petição inicial, assinada por Fábio Konder Comparato e Maurício Gentil Monteiro, a interpretação que estende a anistia a militares e policiais - que cometeram 
crimes de lesa-humanidade - "viola frontalmente diversos preceitos fundamentais da Constituição" 44 . Para um melhor entendimento, transcrevase o dispositivo debatido, o art. $1^{\circ}, \S 1^{\circ}$ da Lei de Anistia:

Art. $1^{\circ}$ É concedida anistia a todos quantos, no período compreendido entre 02 de setembro de 1961 e 15 de agosto de 1979, cometeram crimes políticos ou conexo com estes, crimes eleitorais, aos que tiveram seus direitos políticos suspensos e aos servidores da Administração Direta e Indireta, de fundações vinculadas ao poder público, aos Servidores dos Poderes Legislativo e Judiciário, aos Militares e aos dirigentes e representantes sindicais, punidos com fundamento em Atos Institucionais e Complementares.

$\S 1^{\mathrm{o}}$ - Consideram-se conexos, para efeito deste artigo, os crimes de qualquer natureza relacionados com crimes políticos ou praticados por motivação política.

A norma concede anistia para os crimes políticos, eleitorais e conexos, incluindo-se entre estes os de motivação política, de modo que o ponto central da controvérsia assenta-se na amplitude da expressão "crimes conexos". Para os adeptos da interpretação que tem prevalecido, pelo menos na prática, os crimes comuns praticados pela ditadura militar torturas, desaparecimentos forçados e estupros - foram anistiados por serem conexos a crimes políticos. Entretanto, entendem outros que os prepostos do Estado não praticaram nenhum crime político, logo, tais delitos tampouco podem ser considerados conexos, pois "a conexão criminal supõe que o autor ou os autores de tais crimes perseguiram o mesmo objetivo e não estavam em situação de confronto" 45 . Tal raciocínio parte da premissa de que os delitos políticos (ou por motivação política) e eleitorais foram praticados apenas por opositores do regime militar, assim, os crimes conexos também. Para que se compreenda a fundamentação trazida, necessário se faz definir quais sejam os crimes eleitorais e políticos, para, a partir de então, analisar a natureza dos crimes da repressão.

\footnotetext{
${ }^{44}$ COMPARATO, Fábio Konder; MONTEIRO, Maurício Gentil. Argüição de descumprimento fundamental. Revista $O A B / R J$. Rio de Janeiro, n. 2, v. 25, p. 221, jul./dez. 2009.

45 COMPARATO, Fábio Konder. Crimes sem castigo. Disponível em <http://www.jusbrasil.com.br/noticias/128879/artigo-crimes-sem-castigo-fabio-comparato>. Acesso em 29 ago. 2010.
} 
Os delitos eleitorais estavam, obviamente, previstos no Código Eleitoral, e certamente nenhum agente da repressão praticou qualquer deles. Já “os crimes políticos, na velha e revelha lição de Hungria, são os praticados contra o Estado como unidade orgânica das instituições sociais" ${ }^{\star 46}$, definidos, à época, na legislação que tipificava os crimes contra a segurança nacional e a ordem política e social (Decreto-Lei no 314/67, Decreto-Lei $n^{\circ}$ 898/69 e Lei $n^{\circ}$ 6.620/78). Caracterizam-se pela intenção de subverter a ordem estabelecida, bem como pelo bem jurídico violado. Por sua vez, os crimes de motivação política - também conhecidos como crimes políticos impróprios - se caracterizam pelo animus de atentar contra a ordem política vigente, mesmo não atingindo diretamente bem jurídico da organização política estatal. Em conclusão, os agentes da repressão não cometeram crimes políticos (ou de motivação política) simplesmente porque "não praticaram nenhum dos crimes definidos nesses diplomas legais, pela boa razão de que não atentaram contra a ordem política e a segurança nacional" "47. Os Procuradores da República Marlon Alberto Weichert e Eugênia Gonzaga Fávero esclarecem a classificação:

Crimes políticos são aqueles praticados com motivação política (elemento subjetivo) e em face dos bens jurídicos da ordem pública (elemento objetivo). Ou seja, a caracterização do crime político reclama que a motivação e o bem jurídico violado sejam de natureza política. Trata-se de aplicação da teoria mista: crimes políticos puros (também denominados próprios) são crimes praticados contra o Estado, por motivação política.

Os crimes praticados pelos agentes estatais na repressão à dissidência política não visavam atingir o Estado. Ao contrário, objetivavam "protegê-lo" contra os que pretendiam abalar o poder. Assim, suas condutas não preenchem o requisito objetivo qualificador do crime político, ou seja, não provocavam danos a bens jurídicos da organização política do Estado. Esses ilícitos, ademais, também não eram motivados pelo desejo de atingir o Estado e sequer podem ser considerados crimes políticos impróprios.

\footnotetext{
46 TOURINHO FILHO, Fernando da Costa. Manual de processo penal. São Paulo: Saraiva, 2001. p. 194

${ }^{47}$ COMPARATO, Fábio Konder; MONTEIRO, Maurício Gentil. Argüição de descumprimento fundamental. Revista $O A B / R J$. Rio de Janeiro, n. 2, v. 25, p. 226, jul./dez. 2009.
} 
Os agentes da repressão não agiam de acordo com o elemento subjetivo de "atentar contra a segurança do Estado" (FRAGOSO), ou "inspirados por esse resultado" (HUNGRIA), mas sim para vitimar os que assim faziam.

$[\ldots]$

Logo, esses delitos tampouco podem ser reputados como crimes políticos impróprios, ou relativos, pois sequer foram praticados com motivação política, ou seja, a intenção de praticar lesão ou dano, direto ou indireto, à ordem política. ${ }^{48}$

Passa-se, então, à definição de quais sejam os crimes conexos.

Sendo um requisito da conexão a "identidade ou comunhão de propósitos ou objetivos, nos vários crimes praticados"49, os "crimes conexos são os praticados por uma pessoa ou grupo de pessoas, que se encadeiam em suas causas" ${ }^{, 50}$. Assim, as barbáries cometidas pelo aparato repressivo não podem nunca ser consideradas conexas a crimes políticos, eleitorais ou de motivação política, haja vista a inexistência de vínculo subjetivo entre as condutas de torturadores e torturados. Enquanto os últimos buscavam atingir o Estado, os primeiros buscavam preservá-lo, não havendo que se falar em conexão entre dois crimes antagônicos. Para que as torturas pudessem ser consideradas conexas, os torturadores deveriam ter praticado algum crime político, eleitoral ou por motivação política que estivesse relacionado às mesmas. Reconhecendo-se que não cometeram tais delitos, as torturas só poderiam ser anistiadas se consideradas conexas aos crimes da resistência, o que é juridicamente insustentável. Neste sentido, posiciona-se Hélio Bicudo:

Crimes conexos contemplam as ações de uma ou mais pessoas objetivando o mesmo resultado. Daí se infere que uma é a finalidade daqueles que praticam crimes políticos ou a ele assemelhados (a lei fala, impropriamente, em crimes conexos aos políticos); bem outra é a meta daqueles que torturam e matam em

\footnotetext{
${ }^{48}$ FÁVERO, Eugênia Augusta Gonzaga; WEICHERT, Marlon Alberto. Anistia, tortura, república e democracia. Disponível em 〈http://www.oabsp.org.br/noticias/2010/02/12/5950〉. Acesso em 29 ago. 2010.

${ }^{49}$ FÁVERO, Eugênia Augusta Gonzaga; WEICHERT, Marlon Alberto. Anistia, tortura, república e democracia.

${ }^{50}$ PIOVESAN, Flávia. Direito internacional dos direitos humanos e lei de anistia: o caso brasileiro. Revista anistia política e justiça de transição. Brasília: Ministério da Justiça, n. 2, p. 181, jul./dez. 2009.
} 
nome do Estado ou com seu consentimento. Como falar-se em conexidade, se os crimes de uns vão num sentido e os de outros em sentido inverso?

[...]

Se Tício comete um homicídio e, ao ser detido pela polícia, é, em seguida, morto por um de seus agentes, trata-se de dois crimes absolutamente independentes um do outro. Não se pode considerar o segundo conexo ao primeiro. Pode-se dizer que o primeiro ensejou o segundo, mas não é a ele conexo. Isso quer dizer que os crimes conexos, conforme dispõe a lei, são aqueles cometidos pelo próprio autor ou por quem se tenha associado a ele ${ }^{51}$

A peça exordial ressalta ainda que a chamada conexão intersubjetiva por reciprocidade ${ }^{52}$, prevista no art. 76 , I, in fine do Código de Processo Penal, trata-se apenas de uma regra processual de fixação de competência, não refletindo o instituto de direito material da conexão. Ademais, mesmo que admitida como tal, "os acusados de crimes políticos não agiram contra os que os torturaram e mataram, $[. .$.$] mas contra a ordem política vigente no$ País naquele período"53, afastando qualquer espécie de conexão possível entre os crimes da repressão e os da resistência. Por decorrência lógica, reconhecendo que os agentes do Estado não praticaram crimes políticos ou eleitorais, não houve, tecnicamente, anistia para os crimes da repressão.

A parcela da doutrina que prega a inviabilidade de punição aos crimes da ditadura aponta para a suposta vagueza da expressão "motivação política”, explicando que a mesma possibilitou a extensão da anistia aos crimes em que o agente teve qualquer interesse ideológico no resultado, independentemente da intenção de ofender a ordem política vigente. Neste raciocínio, destaca Lauro Joppert Swensson Junior, em Anistia Penal: Problemas de Validade da Lei de Anistia Brasileira (Lei 6.683/79):

Tanto que, apesar de a maioria dos juristas afirmar que os agentes da repressão política foram sim abrangidos pela anistia, alguns doutrinadores afirmam que não; por exemplo, Dalmo Dallari, Fábio Konder Comparato, Hélio Bicudo, Nilo Batista, entre outros. Para estes autores, a partir da definição que eles assumem

\footnotetext{
51 BICUDO, Hélio. Parecer sobre a anistia. Disponível em <http://www.torturanuncamaisrj.org.br/artigos.asp?Codartigo=36\&Pesq=anistia $>$. Acessado em 29 ago. 2010.

${ }^{52}$ Quando pessoas praticam crimes "umas contra as outras"

53 COMPARATO, Fábio Konder; MONTEIRO, Maurício Gentil. Argüição de descumprimento fundamental. p. 227
} 
de crimes políticos, a Lei 6.683/79 nunca concedeu anistia para tais agentes estatais e colaboradores do regime militar [...]

Contrariamente a esses autores, há quem diga que, para efeitos da interpretação da Lei $6.683 / 79$, o $\S 1^{\circ}$ do art. $1^{\circ}$ resolveu o problema de se saber se os agentes da criminalidade estatal foram anistiados ou não. Quando o art. $1^{\circ}$ dessa lei estabelece que são considerados conexos os crimes de qualquer natureza relacionados com crimes políticos ou praticados por motivação política, poder-seia com isso dizer que os agentes da repressão política acabaram sendo abrangidos pela anistia.

Segundo essa outra parte da doutrina, ainda que não se saiba ao certo o que sejam crimes políticos, é possível obter uma melhor noção do que sejam crimes praticados por motivação política e, mais do que isso, afirmar que os agentes estatais que praticaram crimes durante a repressão política não o faziam por motivos pessoais, mas políticos. [...] Desse modo, é de se pressupor que, a par de certas situações excepcionais, as torturas, os maus-tratos e os vários crimes graves praticados durante a repressão não aconteceram por motivos pessoais dos seus agentes, mas sim por motivos políticos. Ou seja, "cometiam crimes para salvaguardar o Brasil". ${ }^{54}$

Quanto aos os defensores da viabilidade de responsabilização penal, estes são peremptórios em afirmar que crimes de motivação política são exclusivamente os que possuem o elemento subjetivo dos crimes políticos, além de que a fórmula apresentada mostra-se insuficiente, pois caberia analisar caso a caso quando houve "motivação política" ou sadismo, sendo então impossível afirmar de antemão que todos os crimes da repressão estariam anistiados. Por conseguinte, não é possível atribuir aos crimes de estupro, tortura e desaparecimento forçado qualquer motivação política, tendo em vista que, além de não terem a finalidade de atentar contra a ordem política vigente, este conceito "não acolhe as perpetrações de violações de direitos humanos praticadas pelos agentes estatais."55 Nilo Batista, quando da promulgação da Lei de Anistia, afirmou que "a tortura e o homicídio de um preso não são crimes políticos nem conexos a crimes políticos [...] [e] estão a merecer - até quando? - processo e julgamento"56. Entretanto, ao prefaciar a recente obra Justiça de Transição no Brasil:

\footnotetext{
${ }^{54}$ SWENSSON JUNIOR, Lauro Joppert. Anistia Penal: Problemas de Validade Da Lei de Anistia Brasileira (Lei 6.683/79). p. 190-191

${ }^{55}$ FÁVERO, Eugênia Augusta Gonzaga; WEICHERT, Marlon Alberto. Anistia, tortura, república e democracia.

${ }^{56}$ BATISTA, Nilo. Aspectos jurídico-penais da anistia. Revista de Direito Penal. Rio de Janeiro: Forense, n. 26, p. 42, jul./dez. 1979.
} 
Direito, responsabilização e verdade, manifestou-se pela impunidade de tais crimes, tendo em vista o lapso temporal transcorrido. Neste sentido, não haveria como viabilizar a punição dos responsáveis por tais delitos sem ofender o princípio da legalidade, lembrando também "que toda execução penal tardia configura um erro judiciário." ${ }^{\circ 7}$ Neste ponto, mais produtivo é transcrever as palavras do autor:

Lutar por essa tese em 1979, como tantos brasileiros fizemos, era compreensível: ainda havia sangue no piso dos porões, lutava-se pela restauração da legalidade democrática. Trinta anos depois, durante os quais a interpretação da lei - tanto nas escassas ocasiões em que foi o Judiciário provocado quanto na continuada omissão das agências que devem atuar de ofício, como o próprio Ministério Público - invariavelmente reconheceu que a anistia alcançava os torturadores, a luta pela tese, paradoxalmente, ameaça a legalidade democrática. Errávamos em 1979 no calor dos acontecimentos, mas hoje se erra a sangue frio.

[...]

A pena, o utilíssimo placebo com o qual o Estado do empreendimento neoliberal substituiu suas intervenções provedoras, nunca foi capaz de transformar a realidade; ao contrário, as mais importantes transformações históricas provieram de forças em confronto aberto com o sistema penal. $O$ discurso da impunidade do passado termina por dinamizar a demanda conservadora por pena no presente, por alimentar os movimentos de criminalização em curso. Resgatar a memória dos heróis brasileiros imolados na resistência armada à ditadura (memória integrada, sim, pela identidade de seus verdugos) e recuperar, quando for o caso, seus restos mortais para um panteão cujo marco Niemeyer já desenhou envolve um complexo de direitos, nenhum deles concretizável através do processo penal. A interpretação que, como alguns outros admiráveis colegas, tentei construir em 1979 para fazer sentar no banco dos réus os torturadores não era politicamente forte o suficiente para impor-se; hoje, talvez a força exista, mas o preço exorbitante é implodir um dos pilares do Estado de direito restaurado. [...] Podemos, se quisermos, lamentar que a anistia tenha sido tal como foi. Não devíamos ter perdoado a quem perdoamos, não devíamos; mas perdoamos. Agora é tarde. ${ }^{58}$

Este depoimento demonstra a complexidade da discussão, dividindo criminalistas como Nilo Batista, para quem a responsabilização significaria uma afronta ao princípio da legalidade e à democracia, e Eugenio Raúl Zaffaroni, que como membro da Suprema Corte de Justiça Argentina votou

57 BATISTA, Nilo. Nota introdutória. In: DIMOULIS, Dimitri; MARTINS, Antonio; SWENSSON JUNIOR, Lauro Joppet (Org.). Justiça de Transição no Brasil: Direito, responsabilização e verdade. São Paulo: Saraiva, 2010. p. 16

${ }^{58}$ BATISTA, Nilo. Nota introdutória. p. 16-17 
pela impossibilidade de anistia aos crimes contra a humanidade em razão de normas internacionais, como se verá no capítulo 3.

\subsubsection{Da invalidade}

No plano da validade, a Ordem dos Advogados do Brasil aduz que, "ainda que se admita estapafurdiamente essa conexão criminal, ela não é válida," 59 já que foi resultado de uma autoanistia outorgada em pleno regime autoritário, quando o Congresso Nacional encontrava-se coagido e mutilado pelas cassações e "Senadores biônicos". Não há dúvida de que a norma foi obscuramente elaborada pelo Presidente Figueiredo, utilizando-se de expressões genéricas que possibilitaram a sua extensão prática aos agentes da ditadura, promovendo a impunidade de seus próprios crimes. Sustenta-se que, em verdade, nunca houve um acordo nacional a respeito da Lei de Anistia, uma vez que vítimas e familiares nunca concordaram com esta suposta anistia bilateral. ${ }^{60}$ Ademais, mesmo que cientes da intenção do governo de proteger seus criminosos, não havia como ser considerada a vontade dos perseguidos pela repressão - excluindo-se expressamente da anistia os torturadores - em pleno regime ditatorial. Neste caso, ainda que se reconheça o suposto acordo, este já nasceu nulo por vício de consentimento: não havia como negociar com a ditadura, era acatar o que foi outorgado ou nada. Transcreva-se, neste ponto, trecho da petição inicial:

Ressalte-se, em primeiro lugar, que a citada lei foi votada pelo Congresso Nacional, na época em que os seus membros eram eleitos sob o placet dos comandantes militares. Sua carência de legitimidade democrática é acentuada quando se recorda que, por força da Emenda "Constitucional" $\mathrm{n}^{\mathrm{o}} 08$, de 14 de abril de 1977, que ficou conhecida como "Pacote de Abril", 1/3 dos Senadores passaram a ser escolhidos por via de eleição indireta ("Senadores Biônicos"),

\footnotetext{
${ }^{59}$ COMPARATO, Fábio Konder; MONTEIRO, Maurício Gentil. Argüição de descumprimento fundamental. p. 227.

${ }^{60}$ BRASIL. Direito à Memória e à Verdade: Comissão Especial sobre Mortos e Desaparecidos Políticos. Brasília: Secretaria Especial dos Direitos Humanos, 2007. p. 31
} 
tendo participado do processo legislativo do qual redundou a aprovação congressual, em 1979, da lei em referência.

Ela foi sancionada por um Chefe de Estado que era General do Exército e fora guindado a essa posição, não pelo povo, mas pelos seus companheiros de farda. ${ }^{61}$

Como exposto, em uma segunda linha de argumentação, questionouse a própria validade da norma, afirmando-se que, ante estes inequívocos fatos históricos, "a Lei $\mathrm{n}^{\mathrm{o}} 6.683 / 79$ foi um ato normativo produzido formalmente pelo Congresso, mas eivado pelo vício material do regime autoritário". ${ }^{62}$ Sobre o contexto de aprovação da Lei de Anistia, cite-se trecho do artigo A auto-anistia e a farsa de um acordo nacional, de Marcelo Zelic:

A proposta de lei foi enviada pelo general-presidente Figueiredo a um Congresso Nacional de maioria da ARENA, partido do governo, graças à eleição indireta de senadores (os chamados biônicos, casuísmo instituído no Pacote de Abril de 1977, após notável crescimento eleitoral do MDB, partido da oposição); [...]

O Senador Pedro Simon esclarece bem esta questão em seu discurso de encerramento dos trabalhos na Comissão Mista:

"Sem os biônicos, o resultado seria outro; a Lei 6683/79 é resultado da imposição e controle do executivo sobre o legislativo, que buscou, aprovando esta lei, dar uma resposta parcial e restrita às "inquietações sociais" da época e, através do termo crimes conexos, cuja definição não é clara, ao se referir a estes crimes como "de qualquer natureza", deixou impunes os torturadores e excluiu centenas de militantes de organizações de esquerda que resistiram contra o regime-militar, evidenciando o caráter de auto-anistia contido nesta lei, dado o contexto de sua aprovação". ${ }^{63}$

Sendo assim, para adquirir validade, necessário seria que a anistia bilateral fosse expressamente recepcionada pela Constituição Federal de 1988, revestindo-se da devida legitimidade democrática. A recepção da anistia se deu através dos artigos $8^{\circ}$ e $9^{\circ}$ dos Atos das Disposições Constitucionais Transitórias, com a regra geral contida no art. $8^{\circ}$, caput:

\footnotetext{
${ }^{61}$ COMPARATO, Fábio Konder; MONTEIRO, Maurício Gentil. Argüição de descumprimento fundamental. p. 231

${ }^{62}$ FÁVERO, Eugênia Augusta Gonzaga; WEICHERT, Marlon Alberto. Anistia, tortura, república e democracia.

${ }^{63}$ ZELIC, Marcelo. A auto-anistia e a farsa de um acordo nacional.
} 
Art. $8^{\circ}$. É concedida anistia aos que, no período de 18 de setembro de 1946 até a data da promulgação da Constituição, foram atingidos, em decorrência de motivação exclusivamente política, por atos de exceção, institucionais ou complementares, aos que foram abrangidos pelo Decreto Legislativo $\mathrm{n}^{\circ} 18$, de 15 de dezembro de 1961, e aos atingidos pelo Decreto-lei n. ${ }^{\circ} 864$, de 12 de setembro de 1969, asseguradas as promoções, na inatividade, ao cargo, emprego, posto ou graduação a que teriam direito se estivessem em serviço ativo, obedecidos os prazos de permanência em atividade previstos nas leis e regulamentos vigentes, respeitadas as características e peculiaridades das carreiras dos servidores públicos civis e militares e observados os respectivos regimes jurídicos.

Verifica-se que o citado dispositivo refere-se apenas aos que "foram atingidos, em decorrência de motivação exclusivamente política, por atos de exceção". Em momento algum há qualquer menção aos crimes praticados pelos agentes do Estado. Muito pelo contrário: o que se tem é o art. $5^{\circ}$, XLIII da Constituição de 1988 considerando o crime de tortura insuscetível de anistia. Não há como afirmar, em uma interpretação sistemática da Constituição Federal de 1988, que o poder constituinte originário anistiou as torturas e sevícias institucionalizadas nos porões de quartéis e delegacias. $\mathrm{O}$ art. $8^{\mathrm{a}}$ do ADCT concentrou-se apenas na idéia de reparação àqueles que foram prejudicados pela ditadura, no mesmo sentido do que foi pleiteado pelo movimento popular. Em conclusão, a Constituição de 1988, por meio do art. $8^{\circ}$ do ADCT, anistiou apenas os perseguidos políticos, excluindo do benefício os crimes contra a humanidade. ${ }^{64}$ Segundo Lenio Streck, “o art. $8^{\circ}$ do ADCT [...] não concede anistia a qualquer atitude violadora dos direitos humanos". 65

Neste ponto, os que defendem a anistia para as barbáries cometidas pela repressão política afirmam que não há "diferença prática entre afirmar que alguém será processado com base em lei retroativa ou que será

\footnotetext{
64 VENTURA, Deisy et al. O Manifesto dos juristas. Disponível em $<$ http://www.torturanuncamais-rj.org.br/noticias.asp?Codnoticia=184\&ecg=>. Acesso em 4 set. 2010 .

${ }^{65}$ STRECK, Lenio. A Lei de Anistia, a Constituição e os Direitos Humanos no Brasil: Lenio Streck Responde. Revista anistia política e justiça de transição. Brasília: Ministério da Justiça, n. 2, p. 25, jul./dez. 2009.
} 
submetido ao mesmo processo porque a norma de anistia é inválida"66, ou que, após o Superior Tribunal Militar estender o benefício para os militantes de esquerda excluídos da anistia pelo $\S 2^{\text {o67 }}$, esta teria tornado-se “irrestritamente geral, mediante uma jurisprudência com base num argumento de justiça, [que] a desvinculou de uma relação meio/fim portanto, de um cálculo de avaliação da gravidade de atos"68.

Deve-se, aqui, reafirmar que a qualidade de "ampla, geral e irrestrita" popularmente atribuída à Lei de Anistia não se refere à chamada anistia bilateral, destinada a torturados e torturadores. Em estudos jurídicos da época, a expressão "anistia ampla, geral e irrestrita" é encontrada referindo-se apenas aos perseguidos políticos, uma vez que ser ampla significaria anistiar todos os cidadãos punidos com bases em atos institucionais, independentemente do cumprimento de quaisquer requisitos. Cite-se, para tal, o livro Anistia: caminho e solução, de José Ignácio Ferreira, de 1979:

O instituto da Anistia, embora distanciado de suas origens milenares, persiste sintonizado com a generosidade de sua utilização ao longo de nossa história política, aplicando-se não somente aos delitos políticos. A Constituição Federal vigente não estabelece limites ao legislador ordinário para a concessão da anistia que pode e deve ser ampla, geral e irrestrita, alcançando a todos os punidos com base nos Atos Institucionais (ampla), sem exame de mérito dos atos praticados (geral) e sem impor quaisquer condicionamentos aos seus beneficiários (irrestrita). ${ }^{69}$

Por fim, a Ordem dos Advogados do Brasil registra que o Brasil é signatário da Convenção Americana de Direitos Humanos, instrumento que estabelece uma gama de direitos para as vítimas de crimes contra a humanidade, sem esquecer que a jurisprudência da Corte Interamericana de

\footnotetext{
66 DIMOULIS, Dimitri. Justiça de transição e função anistiante no Brasil. Hipostasiações indevidas e caminhos de responsabilização. p. 117

67 " $\$ 2^{\circ}$ - Excetuam-se dos benefícios da anistia os que foram condenados pela prática de crimes de terrorismo, assalto, seqüestro e atentado pessoal."

${ }^{68}$ FERRAZ JR, Tércio Sampaio. Revisão para tudo ficar como está? Disponível em <http://www. terciosampaioferrazjr.com.br/?q=/publicacoes-cientificas/69>. Acesso em 4 set. 2010.

69 FERREIRA, José Ignácio. Anistia: caminho e solução. Vitória: Janc, 1979. p. 77
} 
Direitos Humanos entende por nulas as autoanistias. A isso, acrescenta-se que a dignidade humana é inegociável, invalidando qualquer "acordo" que abrisse mão de direitos inalienáveis, de sorte que não seria possível o Estado se desincumbir da obrigação de investigar e promover a persecução de crimes tão bárbaros que ele mesmo praticou.

\subsection{Da Decisão}

\subsubsection{Contextualização}

Antes de problematizar a decisão, deve-se frisar que a Advocacia Geral da União manifestou-se pelo não conhecimento da ação e, no mérito, pela sua improcedência, enquanto o Procurador-Geral da República, Roberto Monteiro Gurgel Santos, opinou pelo conhecimento e, no mérito, pela improcedência do pedido.

Serão trazidos neste estudo os principais argumentos de mérito invocados pelos Ministros votantes. O Relator do processo foi o Ministro Eros Grau, votando pela improcedência. Também votaram assim os Ministros Marco Aurélio, Cármen Lúcia, Ellen Gracie, Gilmar Mendes, Celso de Mello e Cezar Peluso. Os Ministros Ricardo Lewandowsky e Ayres Britto julgaram o pedido parcialmente procedente. $\mathrm{O}$ Ministro Joaquim Barbosa encontrava-se licenciado, enquanto o Ministro Dias Toffoli julgou-se impedido em razão de ter se manifestado sobra a Lei de Anistia durante o período em que esteve na Advocacia Geral da União.

Preliminarmente, apenas o Ministro Marco Aurélio votou pela extinção do processo sem julgamento de mérito. Sustentando a falta de interesse de agir, afirmou estarem prescritos os fatos de que trata a Lei de Anistia, carecendo a ADPF de adequação. Em que pese ser a imprescritibilidade dos crimes de lesa-humanidade bastante polêmica no Brasil, concluíram os demais Ministros, adotando o entendimento trazido 
pelo Procurador-Geral da República, que a prescrição só deveria ser analisada depois de definido o real alcance da anistia. Ademais, cabe aqui a observação de que é razoável supor que a demanda pretendia muito mais uma declaração do Estado brasileiro do que levar torturadores em idade avançada para as prisões. Requereu-se, em vão e em verdade, que o Estado Democrático de Direito reconhecesse a sua incompatibilidade e repúdio para com as práticas autoritárias e desumanizadoras do passado, dentre as quais as que objetivaram a própria impunidade. Ou seja, que o Judiciário confirmasse, "perante a História, a dignidade transcendental e, portanto, inegociável da pessoa humana" ${ }^{, 70}$.

\subsubsection{Voto do Ministro Eros Grau}

Não foi possível. O voto proferido pelo Ministro Eros Grau - vítima do regime militar - foi emblemático, sendo qualificado por Gilmar Mendes como, "talvez, o seu mais brilhante voto perante esta Corte",71. O Relator inicia sua análise de mérito dissertando sobre o caráter constitutivo da interpretação, distinguindo texto normativo de norma jurídica, para, momentos depois, fazer uma profunda interpretação histórica do dispositivo questionado. O Ministro afirmou que a Lei de Anistia foi fruto de uma "autêntica batalha"72 que resultou no acordo político que era possível à época. Assim, mesmo que injusta, a anistia bilateral teria sido aceita, pois estava condicionada aos "limites materiais da realidade",73. Nesta toada, Eros Grau relembrou a participação da própria $\mathrm{OAB}$ na luta pela anistia, mencionando o parecer elaborado pelo então Conselheiro - e depois ministro do STF - José Paulo Sepúlveda Pertence e encaminhado ao

\footnotetext{
${ }^{70}$ COMPARATO, Fábio Konder; MONTEIRO, Maurício Gentil. Argüição de descumprimento fundamental. Revista $O A B / R J$. p. 234

${ }^{71}$ STF, ADPF no 153/DF, Rel. Ministro Eros Grau, Brasília, 29 abr. 2010

${ }^{72}$ STF, ADPF no 153/DF, Rel. Ministro Eros Grau, Brasília, 29 abr. 2010

${ }^{73}$ STF, ADPF no 153/DF, Rel. Ministro Eros Grau, Brasília, 29 abr. 2010
} 
Senado Federal, no mês de agosto de 1979, em que se reconhece a intenção do regime em anistiar seus prepostos por meio da expressão "crimes conexos". Segundo o Ministro, sabia-se que o texto elaborado pelo Presidente Figueiredo pretendia anistiar também os torturadores a serviço do Estado, e, como a correlação de forças não possibilitava outra forma de anistia, aceitou-se a proposta. Para o Ministro, "é uma lei-medida, não regra para o futuro, dotada de abstração e generalidade. Há de ser interpretada a partir da realidade no momento em que foi conquistada." ${ }^{\text {,4 }}$ Por consequência, a respeito de quais seriam os crimes conexos, Eros afirmou que deve prevalecer a interpretação pretendida, qual seja, a que favorece os crimes de sangue praticados em nome do Estado:

Essa expressão, crimes conexos a crimes políticos, conota sentido a ser sindicado no momento histórico da sanção da lei. Sempre há de ter sido assim. A chamada Lei de anistia diz com uma conexão sui generis, própria ao momento histórico da transição para a democracia. Tenho que a expressão ignora, no contexto da Lei $\mathrm{n}$. $6.683 / 79$, o sentido ou os sentidos correntes, na doutrina, da chamada conexão criminal. Refere o que "se procurou", segundo a inicial, vale dizer, estender a anistia criminal de natureza política aos agentes do Estado encarregados da repressão. ${ }^{75}$

Afirma ainda não competir ao Judiciário "rescrever leis de anistia"76, sob pena de ofender o princípio da separação de poderes. Caberia, no caso, ao Legislativo "revisar" a Lei de Anistia. Parte-se aqui da premissa de que não há dúvida acerca da vontade do legislador em anistiar os torturadores, logo, interpretar diversamente implicaria "alterar textos normativos concessivos de anistias." 77 Nos termos do voto:

Cabe bem lembrar, neste passo, trecho do voto do Ministro Orosimbo Nonato no Recurso Extraordinário Criminal n. 10.177, julgado em 11 de maio de 1948: "Ao Poder Judiciário cabe apenas o encargo de interpretar a lei que traduz a anistia,

\footnotetext{
${ }^{74} \mathrm{STF}, \mathrm{ADPF} \mathrm{n}^{\circ}$ 153/DF, Rel. Ministro Eros Grau, Brasília, 29 abr. 2010

${ }^{75} \mathrm{STF}, \mathrm{ADPF} \mathrm{n}^{\circ}$ 153/DF, Rel. Ministro Eros Grau, Brasília, 29 abr. 2010

${ }^{76} \mathrm{STF}, \mathrm{ADPF} \mathrm{n}^{\circ}$ 153/DF, Rel. Ministro Eros Grau, Brasília, 29 abr. 2010

${ }^{77}$ STF, ADPF no 153/DF, Rel. Ministro Eros Grau, Brasília, 29 abr. 2010
} 
sua extensão e alcance quanto aos fatos e às pessoas. No que tange ao mais, nada lhe cumpre fazer. [...]"

[...]

46. Há quem sustente que o Brasil tem uma concepção particular de lei, diferente, por exemplo, do Chile, da Argentina e do Uruguai, cujas leis de anistia acompanharam as mudanças do tempo e da sociedade. Esse acompanhamento das mudanças do tempo e da sociedade, se implicar necessária revisão da lei de anistia, deverá contudo ser feito pela lei, vale dizer, pelo Poder Legislativo. Insisto em que ao Supremo Tribunal Federal não incumbe legislar sobre a matéria.

Revisão de lei de anistia, se mudanças do tempo e da sociedade a impuserem, haverá - ou não - de ser feita pelo Poder Legislativo, não pelo Poder Judiciário. ${ }^{78}$

Ora, Eros Grau cita o Ministro Orosimbo Nonato para asseverar que ao Judiciário cabe apenas a tarefa de interpretar e delimitar o alcance das leis de anistia. Pergunta-se: não era exatamente o que se pretendia com a Arguição de Descumprimento de Preceito Fundamental no 153 ?

Por fim, o jurista prega a recepção da Lei de Anistia pela Emenda Constitucional $\mathrm{n}^{\mathrm{o}} 26$, de 27 de novembro de 1985 - a mesma que deu poderes aos membros do Congresso Nacional para reunirem-se em Assembléia Nacional Constituinte. Em seu art. $4^{\circ}, \S 1^{\circ}$, prevê a EC $n^{\circ}$ 26/85:

Art. $4^{\circ}$ É concedida anistia a todos os servidores públicos civis da Administração direta e indireta e militares, punidos por atos de exceção, institucionais ou complementares.

$\S 1^{\circ}$ É concedida, igualmente, anistia aos autores de crimes políticos ou conexos, e aos dirigentes e representantes de organizações sindicais e estudantis, bem como aos servidores civis ou empregados que hajam sido demitidos ou dispensados por motivação exclusivamente política, com base em outros diplomas legais.

Entendeu o Ministro Relator que a EC $n^{\circ}$ 26/85 significou a legitimação, pelo poder constituinte originário, da Lei de Anistia. Embora o dispositivo também não se dirija expressamente aos crimes cometidos pela repressão - mencionando apenas os sujeitos punidos por atos de exceção -, afirmou que a EC no 26/85 repetiu a intenção da Lei $n^{\circ}$ 6.683/79. Em

\footnotetext{
${ }^{78}$ STF, ADPF no 153/DF, Rel. Ministro Eros Grau, Brasília, 29 abr. 2010
} 
verdade, aqui cabe a crítica de que, apesar do art. $4^{\circ}, \S 1^{\circ}$ da $\operatorname{EC} n^{\circ} 26 / 85$ repetir a anistia "aos autores de crimes políticos ou conexos", a norma não se refere aos de "motivação política", como fez a Lei de Anistia. E, como já se viu, é justamente entre estes últimos que a doutrina defensora da anistia bilateral encaixa os crimes da repressão. ${ }^{79}$ Ademais, de qualquer forma, a Lei de Anistia teria que ser recepcionada pela Constituição Federal de 1988, tendo em vista a incondicionalidade do poder constituinte originário. Eros Grau, em conclusão, afirma que "não se pode divisar antinomia de qualquer grandeza entre o preceito veiculado pelo $\S 1^{\circ}$ do artigo $4^{\circ}$ da EC/85 e a Constituição de 1988." ${ }^{\text {" }}$ Porém, analisando os três dispositivos, verifica-se que, enquanto a Lei de Anistia beneficia os crimes eleitorais, políticos ou conexos aos de motivação política, a EC n ${ }^{\circ}$ 26/85 não menciona os de motivação política. Ao fim, ainda mais restritivamente, o art. $8^{\circ}$ do ADCT refere-se apenas aos atingidos pelos atos de exceção.

\subsubsection{Voto da Ministra Cármen Lúcia}

O voto da Ministra Cármen Lúcia apega-se também à interpretação histórica do dispositivo questionado, afirmando que a Lei de Anistia "permitiu uma transição institucional". ${ }^{81}$ Muito embora reconheça que não há conexão criminal entre os crimes de tortura e os de natureza política, a Ministra afirma não ser possível, 30 anos depois, alterar retroativamente a interpretação da lei em desfavor dos autores dos crimes, mesmo também sem concordar que a $\mathrm{EC} \mathrm{n}^{\circ}$ 26/85 integre o sistema constitucional, não podendo ser considerada a recepção da Lei de Anistia.

\footnotetext{
${ }^{79}$ SWENSSON JUNIOR, Lauro Joppert. Positivismo, realismo e moralismo jurídicos no debate sobre a responsabilização penal para os crimes da ditadura militar: Revista anistia política e justiça de transição. Brasília: Ministério da Justiça, n. 2, p. 333, jul./dez. 2009.

${ }^{80} \mathrm{STF}$, ADPF no 153/DF, Rel. Ministro Eros Grau, Brasília, 29 abr. 2010

${ }^{81} \mathrm{STF}, \mathrm{ADPF} \mathrm{n}^{\circ}$ 153/DF, Rel. Ministro Eros Grau, Brasília, 29 abr. 2010
} 


\title{
2.2.4. Voto do Ministro Ricardo Lewandowsky
}

O primeiro voto divergente partiu do Ministro Ricardo Lewandowsky. Fazendo uma contextualização histórica da Lei de Anistia, também identifica a crise econômica de 1974 como a alavanca para a decadência do regime ditatorial. Assim, convencidos de que eram necessárias mudanças institucionais, os militares as fizeram, "embora de forma controlada." $"$ Neste contexto, outorgaram uma anistia que, pretendendo beneficiar carrascos e torturadores, não poderia $\mathrm{o}$ fazer expressamente, sob pena de confessar a existência de torturas, desaparecimentos forçados e estupros, o que nunca fora admitido pelas Forças de Segurança. O Ministro sabiamente reconhece a voluntas legislatoris de se anistiar os agentes da repressão, entretanto, afirma que deve prevalecer a "voluntas legis, cuja avaliação se faz a partir de critérios hermenêuticos mais objetivos." ${ }^{83}$ Segundo Lewandowsky:

\begin{abstract}
A partir de uma perspectiva estritamente técnico-jurídica, pois, não há como cogitar-se de conexão material entre os ilícitos sob exame, conforme pretenderam os elaboradores da Lei de Anistia, porquanto não é possível conceber tal liame entre os crimes políticos comuns alegadamente cometidos por aqueles que se colocavam a seu serviço, visto inexistir, com relação a eles, o necessário nexo teleológico, consequencial ou ocasional exigido pela doutrina para a sua caracterização. $^{84}$
\end{abstract}

Em seguida, o eminente Ministro invoca a jurisprudência do Supremo Tribunal Federal para definir o que sejam crimes políticos. Em diversos casos de extradição (Caso Norambuena ${ }^{85}$ e Caso Battisti ${ }^{86}$ ) o STF tem identificado os crimes políticos através dos critérios da preponderância

\footnotetext{
${ }^{82} \mathrm{STF}, \mathrm{ADPF} \mathrm{n}^{\circ}$ 153/DF, Rel. Ministro Eros Grau, Brasília, 29 abr. 2010

${ }^{83} \mathrm{STF}, \mathrm{ADPF} \mathrm{n}^{\circ}$ 153/DF, Rel. Ministro Eros Grau, Brasília, 29 abr. 2010

${ }^{84} \mathrm{STF}, \mathrm{ADPF} \mathrm{n}^{\circ}$ 153/DF, Rel. Ministro Eros Grau, Brasília, 29 abr. 2010

${ }^{85}$ STF, Ext n ${ }^{\text {o } 855, ~ R e l . ~ M i n i s t r o ~ C e l s o ~ d e ~ M e l l o, ~ B r a s i ́ l i a, ~} 26$ ago. 2004

${ }^{86}$ STF, Ext no 1085, Rel. Ministro Gilmar Mendes, Brasília, 16 dez. 2009
} 
e da atrocidade dos meios utilizados. Foi citado como referência o votovista do Ministro Gilmar Mendes no Caso Battisti:

Na jurisprudência do Supremo Tribunal destacam-se que os casos em que, na solução de difíceis problemas quanto à definição de crime político, conjugam-se os critérios da preponderância e da atrocidade dos meios.

(...)

O Supremo Tribunal Federal, ao tratar de situações em que se cogita da natureza política ou comum dos delitos, para fins de extradição, tem, constantemente, tratado de forma absolutamente diferenciada os crimes violentos, praticados contra a pessoa, especialmente no que respeita ao direito à vida e à liberdade. Ainda que sua finalidade seja política, ou políticos os motivos, tais delitos, especialmente os chamados 'delitos de sangue', vêm sendo, sistematicamente, tratados como comuns, por exacerbarem os limites éticos das lutas pela liberdade e pela democracia. ${ }^{87}$

Assim, entendeu o Ministro que as ações penais poderiam sim ser desencadeadas contra os agentes da repressão, "desde que [o Juiz ou Tribunal] descarte, caso a caso, a prática de um delito de natureza política, mediante a aplicação dos critérios acima referidos." Lewandowsky afirma ainda que a reprodução da anistia pela Emenda Constitucional no 26/85 foi inócua, "porque, teoricamente, uma lei de anistia surte efeitos imediatos" além de que a emenda padece dos mesmos vícios inerentes à Lei $n^{\circ}$ 6.683/79. Por último, invoca o princípio da inafastabilidade de jurisdição como imposição para o Estado investigar e punir violações de direitos humanos, bem como a força dos tratados internacionais.

\subsubsection{Voto do Ministro Ayres Britto}

O Ministro Ayres Britto iniciou seu voto afirmando que "para a coletividade perdoar certos infratores, é preciso que o faça por modo claro, assumido, autêntico, não incidindo em tergiversação redacional" ${ }^{\prime 9}$. Critica-

\footnotetext{
${ }^{87}$ STF, Ext $n^{\circ}$ 1085, Rel. Ministro Gilmar Mendes, Brasília, 16 dez. 2009 apud STF, ADPF $\mathrm{n}^{\circ}$ 153/DF, Rel. Ministro Eros Grau, Brasília, 29 abr. 2010

${ }^{88}$ STF, ADPF no 153/DF, Rel. Ministro Eros Grau, Brasília, 29 abr. 2010

${ }^{89} \mathrm{STF}, \mathrm{ADPF} \mathrm{n}^{\circ}$ 153/DF, Rel. Ministro Eros Grau, Brasília, 29 abr. 2010
} 
se o voto do Ministro Eros Grau por apegar-se demasiadamente ao método histórico de interpretação, sendo este apenas "um paramétodo de interpretação jurídica"90:

[...] eu não consigo enxergar no texto da Lei da Anistia essa clareza que outros enxergam, com tanta facilidade, no sentido de que ela, Lei da Anistia, sem dúvida incluiu no seu âmbito pessoal de incidência todas as pessoas que cometeram crimes, não só os singelamente comuns, mas os caracteristicamente hediondos ou assemelhados, desde que sob motivação política ou sob tipificação política. [...]

O Ministro Eros Grau, ontem, nos brindou a todos com um voto cuidadoso, detalhado. Sua Excelência colocou muita ênfase para reproduzir os precedentes ou as tratativas da lei, mas não tanto na vontade objetiva desse diploma legal. Ou seja, atentou bem mais para os precedentes do que para a lei em si [...]

Ou seja, o método histórico não é para afastar a priori qualquer dúvida; [...] E, nesse caso da Lei da Anistia, eu não tenho nenhuma dúvida de que os crimes hediondos e equiparados não foram incluídos no chamado relato ou núcleo deôntico da lei."

Para o eminente jurista, "o que interessa é a vontade objetiva da lei, não é a vontade subjetiva do legislador" ${ }^{\circ 2}$, e, neste caso, a lei não beneficia quaisquer crimes de lesa-humanidade. Assim, diante de mais de uma interpretação possível, deve prevalecer sempre a que esteja conforme a Constituição, excluindo-se da anistia "os crimes hediondos e os que the sejam equiparados: homicídio, tortura e estupro, especialmente." ${ }^{, 93}$ Salientase, em seu voto, a diferença entre os crimes políticos e os abusos cometidos pelos agentes da repressão que, não satisfeitos com o autoritarismo então vigente, estupraram e torturaram violando inclusive as próprias leis de exceção, vez que estas não autorizavam, pelo menos deliberadamente, a tortura. Inconcebível, nestes casos, a atribuição de motivação política a tais crimes.

Quem redigiu essa lei não teve coragem - digamos assim - de assumir essa propalada intenção de anistiar torturadores, estupradores, assassinos frios de

\footnotetext{
${ }^{90} \mathrm{STF}, \mathrm{ADPF} \mathrm{n}^{\circ}$ 153/DF, Rel. Ministro Eros Grau, Brasília, 29 abr. 2010

${ }^{91} \mathrm{STF}, \mathrm{ADPF} \mathrm{n}^{\circ}$ 153/DF, Rel. Ministro Eros Grau, Brasília, 29 abr. 2010

${ }^{92} \mathrm{STF}, \mathrm{ADPF} \mathrm{n}^{\circ}$ 153/DF, Rel. Ministro Eros Grau, Brasília, 29 abr. 2010

${ }^{93} \mathrm{STF}, \mathrm{ADPF} \mathrm{n}^{\circ}$ 153/DF, Rel. Ministro Eros Grau, Brasília, 29 abr. 2010
} 
prisioneiros já rendidos; pessoas que jogavam de um avião em pleno vôo as suas vítimas; pessoas que ligavam fios desencapados a tomadas elétricas e os prendiam à genitália feminina; pessoas que estupravam mulheres na presença dos pais, dos namorados, dos maridos. [...]

O torturador é um monstro, é um desnaturado, é um tarado. O torturador é aquele que experimenta o mais intenso dos prazeres diante do mais intenso dos sofrimentos. É uma espécie de cascavel de ferocidade tal que morde até o som dos próprios chocalhos. Não se pode ter condescendência com ele. Mas, convenhamos, a Lei da Anistia podia, por deliberação do Congresso Nacional, anistiar os torturadores. Digamos que sim, mas que o fizesse claramente, sem tergiversação. E não é isso o que eu consigo enxergar na Lei de Anistia.

[...] Antipessoa que é pior do que um animal. Isto é, além de não ser pessoa, é pior do que um animal, porque o animal não tortura. Mas a lei que anistiar um monstro, que assim o diga. E me parece que a lei não o disse. ${ }^{94}$

A respeito da $E C n^{\circ} 26 / 85$, o Ministro defende que, bem como o art. $8^{\circ}$ do ADCT, esta se refere apenas aos que foram atingidos por motivos políticos. Ademais, em seu entendimento, a afirmação de que a anistia foi definitivamente constitucionalizada pela referida emenda não procede, haja vista a incondicionalidade do poder constituinte originário. ${ }^{95}$

\subsubsection{Votos dos Ministros Ellen Gracie e Marco Aurélio:}

Na sequência, votaram os Ministros Ellen Gracie e Marco Aurélio, que basicamente acompanharam o voto do Ministro Relator Eros Grau, destacando não ter sido a Lei $n^{\circ} 8.863 / 79$ uma autoanistia.

\subsubsection{Voto do Ministro Celso de Mello}

O Ministro Celso de Mello, por sua vez, reconheceu que a jurisprudência da Corte Interamericana de Direitos Humanos tem como nulas as leis de autoanistia, entretanto, afirma que o caso brasileiro tratou-se de um legítimo acordo político, reconhecendo ainda o problema da prescrição, caso fosse julgada procedente a ação.

\footnotetext{
${ }^{94}$ STF, ADPF n ${ }^{\text {o }}$ 153/DF, Rel. Ministro Eros Grau, Brasília, 29 abr. 2010

${ }^{95}$ STF, ADPF no 153/DF, Rel. Ministro Eros Grau, Brasília, 29 abr. 2010
} 


\subsubsection{Voto do Ministro Cezar Peluso}

O Ministro Cezar Peluso atentou para o "sentido metajurídico"96 da conexão empregada no texto legal, bem como para a falta de repercussão prática da $\mathrm{ADPF}$ em razão da suposta prescrição, criticando a $\mathrm{OAB}$ por ter questionado a luta pela anistia quase 30 anos após ter participado diretamente da mesma.

\subsubsection{Voto do Ministro Gilmar Mendes}

Por último, o Ministro Gilmar Mendes destacou que "a questão não reside na conceituação do que seja crime político, e sim na própria característica do ato de anistia. ${ }^{, 97}$ Para o Ministro, a anistia tem caráter político por excelência, além de que a $E C \mathrm{n}^{\circ}$ 26/85 teria incorporado "a anistia como um dos fundamentos da nova ordem constitucional que se construía à época" 98 .

\subsubsection{Breves considerações}

Mais do que apresentar argumentos jurídicos consistentes, a decisão proferida pelo Supremo Tribunal Federal evidenciou a enorme dificuldade política de se fazer uma justiça de transição no Brasil. Indubitavelmente, esta dificuldade enfrentada está diretamente ligada à forte influência política exercida pelos remanescentes da ditadura - não apenas militares, mas também políticos, juristas e empresários. Lauro Joppert Swensson Junior, ao analisar a viabilidade política destas responsabilizações, assim conclui:

\footnotetext{
${ }^{96} \mathrm{STF}, \mathrm{ADPF} \mathrm{n}^{\text {o }}$ 153/DF, Rel. Ministro Eros Grau, Brasília, 29 abr. 2010

${ }^{97}$ STF, ADPF no 153/DF, Rel. Ministro Eros Grau, Brasília, 29 abr. 2010

${ }^{98}$ STF, ADPF n ${ }^{\text {o }}$ 153/DF, Rel. Ministro Eros Grau, Brasília, 29 abr. 2010
} 


\begin{abstract}
Além disso, nada garante que uma sociedade considerada tradicionalmente pacífica não possa vir a exigir o castigo a todos os responsáveis pelos crimes da repressão política.

A punição dos acusados da criminalidade da repressão política depende ainda da força ou do poder remanescente dos antigos líderes e demais pessoas responsáveis pelo regime autocrático anterior. Se o poder dessas pessoas for ainda muito grande, haverá grande resistência contra a punição dos envolvidos na criminalidade estatal e o risco, se a punição ocorrer, de se realizar um novo gole de Estado. Muitas vezes, a transição democrática só é possível mediante um acordo entre as novas e antigas autoridades políticas, em que é combinado não se punir ninguém pela criminalidade estatal do passado. ${ }^{99}$
\end{abstract}

Desta forma, a Arguição de Descumprimento Fundamental $\mathrm{n}^{\circ} 153$ expôs a falta de interesse, por parte do Supremo Tribunal Federal, na judicialização desta questão política, abstendo-se de promover o ativismo judicial que recentemente tem sido uma constante em suas decisões. O que se verifica é que o Pretório Excelso tem sido extremamente seletivo na judicialização da política, restando saber o motivo pelo qual se recusa a promover uma justiça de transição efetiva - tendo em vista a improcedência da ADPF n ${ }^{\circ} 153$ e a ausência de julgamento das ADIn's no 3987 e 4077, que pretendem a abertura dos arquivos da repressão. Salta aos olhos que, na decisão, o STF tenha desconsiderado a própria jurisprudência relativa à caracterização de crimes praticados por motivação política (critérios da preponderância e da atrocidade dos meios). Entretanto, o que impressionou sobremodo foi o STF ter asseverado que a anistia recíproca resultou de um amplo acordo nacional. Afirmar - como fez o Supremo Tribunal Federal que a anistia bilateral foi resultado de um legítimo acordo nacional para anistiar torturados e torturadores é violentar a História. A anistia bilateral, se houve, foi imposta pelo Estado de exceção a um Congresso Nacional ilegítimo. É inequívoco que o movimento pela anistia militou em prol dos perseguidos políticos, daqueles homens e mulheres que estavam presos, banidos ou exilados. Não faria sentido, inclusive, anistiar torturadores que

\footnotetext{
${ }^{99}$ SWENSSON JUNIOR, Lauro Joppert. Anistia Penal: Problemas de Validade Da Lei de Anistia Brasileira (Lei 6.683/79). p. 123-124
} 
sequer tinham sido investigados por seus crimes. Conforme já tratado no capítulo 1 deste estudo, sabe-se que a luta pela anistia exigiu a persecução penal dos responsáveis pelos crimes da repressão. Logicamente, a ditadura utilizou seus meios autoritários para anistiar seus crimes, e notadamente conseguiu. Em emblemática síntese, a fundamentação vencedora está contida no parágrafo em que o Ministro Eros Grau diz não caber ao Judiciário "rever" a Lei de Anistia:

O segundo ponto a ser considerado está em que --- se o que "se procurou", segundo a inicial, foi a extensão da anistia criminal de natureza política aos agentes do Estado encarregados da repressão --- a revisão desse desígnio haveria de ser procedida por quem se procurou estende-la [sic] aos agentes do Estado encarregados da repressão, isto é, pelo Poder Legislativo. Não pelo Poder Judiciário. $^{100}$

Este mesmo argumento foi invocado em 1987, na primeira vez em que a Corte Suprema de Justiça da Argentina analisou a constitucionalidade de suas leis de anistia. Como já se disse, o referido tribunal declarou posteriormente a invalidade das mesmas. Enfim, "Eros Grau, ao fim e ao cabo, decidiu não decidir. Fechou as portas do Judiciário e nos remeteu ao bispo - no caso, o Legislativo."101 O Supremo Tribunal Federal perdeu uma excelente oportunidade de dar um importante passo na virada dessa página obscura da História do país, declarando a incompatibilidade da autoanistia de crimes contra a Humanidade com a atual ordem democrática. Não o fez. Segundo Luiz Flávio Gomes, o julgamento foi marcado pelo desprezo aos direitos das vítimas da repressão. ${ }^{102}$ É lamentável que se tenha optado pela impunidade de crimes tão bárbaros, oriundos de um golpe de Estado e praticados contra a população civil. Enquanto parcela desta foi perseguida,

\footnotetext{
${ }^{100}$ STF, ADPF n ${ }^{\circ}$ 153/DF, Rel. Ministro Eros Grau, Brasília, 29 abr. 2010

${ }^{101}$ FELIPPE, Marcio Sotelo. Lei de anistia foi estratégia da ditadura. Disponível em $<$ http://www.conjur.com.br/2010-maio-07/lei-anistia-foi-apenas-produto-estrategia-politicaditadura $>$. Acesso em 12 set. 2010.

${ }^{102}$ GOMES, Luiz Flávio. Lei de anistia: brilharam pela ausência as vítimas e seus direitos. Disponível em <http://www.novacriminologia.com.br/artigos/artigoler.asp?idartigo=2700>. Acesso em 28 ago. 2010.
} 
torturada, morta, exilada ou condenada a passar anos na prisão, os agentes da repressão sequer foram investigados. Daí a ofensa à isonomia por parte deste perigoso estímulo chamado de anistia bilateral.

Contudo, apesar do Supremo Tribunal Federal ter julgado improcedente a ADPF $\mathrm{n}^{\circ} 153$, a discussão acerca da validade da Lei de Anistia não está encerrada, tendo em vista que as vítimas e familiares vêm buscando, através do sistema interamericano de direitos humanos, seus direitos garantidos pela Convenção Americana. Assim, o caso brasileiro foi levado à Corte Interamericana, que a qualquer momento divulgará sua sentença no processo internacional movido contra o Estado brasileiro. 


\section{A CORTE INTERAMERICANA DE DIREITOS HUMANOS}

\subsection{Do Caso Guerrilha do Araguaia x Brasil}

\subsubsection{A Guerrilha do Araguaia}

A Guerrilha do Araguaia foi um movimento político-militar de resistência à ditadura, organizado sob a direção do Partido Comunista do Brasil, instalado às margens do Rio Araguaia, norte do atual estado de Tocantins. Os primeiros guerrilheiros chegaram em 1967: instalaram-se entre a população local, trabalharam na terra e ambientaram-se à vida na floresta. Os combates se iniciaram no início de 1972, alongando-se até 1975. Nestes anos, o regime militar institucionalizara a tortura - consagrada como o instrumento mais eficiente da repressão - e os desaparecimentos forçados, elegendo a resistência como única alternativa política para os irredutíveis. "Boa parte desses homens e mulheres que se embrenharam nas matas do Araguaia era composta de lideranças estudantis que haviam participado de importantes manifestações contra a ditadura militar," ${ }^{103}$ de sorte que já haviam sido presos ou estavam sendo procurados, sujeitos a iminentes mortes e tortura. Muitos foram enviados à região da guerrilha justamente para escapar do cerco que a repressão mantinha nos grandes centros urbanos. Em verdade, optaram pela luta guerrilheira como meio de defesa da própria vida - ou não - e derrubada da ditadura, tendo como objetivo final a instalação da República Socialista no Brasil, que até o Golpe Militar de 1964 buscavam pela via democrática.

Apesar de receberem o apoio da população local - principalmente pelas atividades sociais que desenvolviam -, os guerrilheiros possuíam uma força bélica precária, cujo armamento padrão era o revólver calibre 38, já

\footnotetext{
${ }^{103}$ BRASIL. Direito à Memória e à Verdade. p. 195
} 
que a média era de uma arma longa para cada dois guerrilheiros. ${ }^{104}$ Assim, embora tenham obtido significativas vitórias nas duas primeiras campanhas militares, terminaram aniquilados pela brutalidade da repressão. Sobre os combates no Araguaia, transcreva-se o depoimento do ex-guerrilheiro José Genoino:

Os combates se revestiram de crueldade e violência. Alguns guerrilheiros tiveram suas cabeças colocadas como prêmio, os corpos eram dependurados em helicópteros, como aconteceu com o de Osvaldo Orlando da Costa. Helenira, presa ferida, foi morta a baioneta. Kleber foi preso com malária e morto também a golpes de baioneta. O corpo do Arildo foi encontrado sem cabeça depois de duro combate. Esses são os casos mais conhecidos, de desrespeito às próprias leis da guerra e de um mínimo respeito à pessoa humana, mesmo depois de morta. $\mathrm{O}$ corpo de João Carlos Hass foi exposto em praça pública, como tentativa de intimidação da população que o estimava.

Muitas prisões eram efetuadas na região, dentre as quais as de alguns guerrilheiros. A prática das torturas era rotina dentro das bases construídas nas cidades e povoados, executadas publicamente. ${ }^{105}$

Sobre algumas das torturas praticadas pela repressão militar no Araguaia, cite-se o livro Direito à Memória e à Verdade:

O jornalista Fernando Portela, que em 1979 escreveu várias matérias sobre o Araguaia no Jornal da Tarde, escreveu: "A tortura foi sistemática. Em Xambioá, cavaram-se buracos próximos ao acampamento e os homens foram pendurados de cabeça para baixo, amarrados com cordas em estacas afiadas à beira dos buracos. Levavam empurrões, socos e choques elétricos. E havia um médico entre os 'especializados'. Quando um homem desmaiava, recebia uma injeção para reanimar e sofrer consciente. Vários morreram em consequiência dos maus tratos sofridos e alguns enlouqueceram. A quase totalidade não havia participado da guerrilha, mas teve o azar de ter vendido mantimento, transportado, cortado o cabelo ou conversado, em algum momento, com um dos componentes da guerrilha. Ou mesmo ter feito um comentário positivo ou complacente sobre os jovens paulistas que viviam e lutavam contra o governo. Naquela época, e naquele lugar, qualquer sinal de simpatia por eles era visto como um perigoso ato de contestação ao regime, tão perigoso quanto pegar em armas". ${ }^{106}$

${ }^{104}$ GASPARI, Elio. A ditadura escancarada. p. 416

105 NETO, José Genoino. A Guerrilha do Araguaia. In: CABRAL, Reinaldo; LAPA, Ronaldo (Org.). Desaparecidos Políticos: prisões seqüestros assassinatos. Rio de Janeiro: Comitê Brasileiro pela Anistia, 1979. p. 198

${ }^{106}$ BRASIL. Direito à Memória e à Verdade. p. 195 
A ordem era não fazer prisioneiros. Guerrilheiros eram capturados vivos, torturados por alguns dias e executados posteriormente. A repressão sequer admitia a existência da guerrilha, empenhando-se em desaparecer com os corpos e apagar as provas das atrocidades cometidas. A imprensa estava proibida de dar qualquer notícia sobre o conflito, e, mesmo com o seu término, as operações militares na região prosseguiram:

Da guerrilha do Araguaia só há um relato assumido de oficial combatente. É o do capitão Pedro Correa Cabral, feito mais de vinte anos depois, quando ele já era coronel da reserva: "A guerrilha já não era mais guerrilha. Era uma caçada levada a termo por verdadeiros monstros." Cabral revelou que helicópteros sobrevoaram a selva com alto-falantes por meio dos quais se oferecia a rendição aos guerrilheiros. Quem acreditou, foi assassinado. ${ }^{107}$

O fato é que, quase 40 após o fỉm da insurgência no Araguaia, cerca de 70 militantes mortos no conflito ainda restam desaparecidos, com as exceções de Maria Lúcia Petit da Silva e Bergson Gurjão Farias. Em 1996, o jornal $O$ Globo publicou uma foto exibindo dois guerrilheiros executados, sendo um deles Maria Lucia Petit, cujo corpo havia sido exumado em 1991, no cemitério de Xambioá, por legistas da Unicamp que não conseguiram identificá-la de pronto. Após a publicação da foto, verificou-se que o cadáver encontrava-se vestido com as mesmas roupas - também enrolado em um pára-quedas -, sendo finalmente reconhecida pela Unicamp e entregue à família para ser sepultada. A ossada de Bérgson Gurjão, por outro lado, havia sido encontrada em 1996, também no cemitério de Xambioá, vindo a ser identificada em 2009. Estes dois casos não deixam dúvidas acerca da existência de outros corpos que devem ser entregues às famílias. Paradoxalmente, todas as demais buscas esbarram na falta de informações - tendo em vista que as Forças Armadas negam a existência de arquivos, amparadas pela Lei $n^{\circ} 11.111 / 05$ - e no medo que a população

${ }^{107}$ GASPARI, Elio. A ditadura escancarada. p. 453 
local tem de colaborar, aterrorizada pelas ameaças do Exército. ${ }^{108}$ Lembrese que os desaparecimentos, em sua grande maioria, não tratam de mortos em combate na selva, mas da tortura e execução de prisioneiros que estavam sob a guarda do Estado. Neste sentido, não há dificuldade logística que justifique o suposto desconhecimento do paradeiro dos corpos por parte das forças de segurança ${ }^{109}$; muito pelo contrário, realizaram-se operações militares exclusivamente para sumir com quaisquer indícios de mortes e torturas. $^{110}$

\subsubsection{A Convenção Americana de Direitos Humanos}

Por diversos meios os familiares dos desaparecidos políticos do Araguaia tentaram localizar o paradeiro de seus respectivos pais, filhos, irmãos. Entretanto, diante de obstáculos intransponíveis como o sigilo absoluto de documentos referentes ao conflito e a aplicação da Lei de Anistia, todas as tentativas de enterrar seus mortos terminam frustradas. Em 19 de fevereiro de 1982, 22 familiares, representando 25 desaparecidos do Araguaia, ingressaram com uma ação ordinária perante a Justiça Federal requerendo o esclarecimento, por parte do Estado brasileiro, das mortes dos militantes, possibilitando a localização de seus corpos. Os autos foram tombados sob o $\mathrm{n}^{\mathrm{o}} 82.00 .24682-5$ e, em 27 de março de 1989, foi extinto sem julgamento de mérito. Interposta apelação, após morosos cinco anos, dia 17 de agosto de 1993, o Tribunal Regional Federal deferiu o recurso por unanimidade. Entretanto, a União recorreu aos tribunais superiores, retardando ainda mais o processo. Em 30 de junho de 2003, a Juíza Federal Titular da $1^{\text {a }}$ Vara Federal da Seção Judiciária do Distrito Federal assinou a sentença que condenou a União, entre outras coisas, a quebrar o sigilo das

\footnotetext{
${ }^{108}$ BRASIL. Direito à Memória e à Verdade. p. 42

${ }^{109}$ GASPARI, Elio. A ditadura escancarada. p. 420

${ }^{110}$ BRASIL. Direito à Memória e à Verdade. p. 199
} 
informações militares referentes à guerrilha e informar a localização dos corpos. Infelizmente, mesmo com o trânsito em julgado, não houve a mínima satisfação das medidas, uma vez que o Exército alega a inexistência de tais arquivos. Ante a contínua e injustificada omissão do Estado Brasileiro, o Grupo Tortura Nunca Mais/RJ, a Comissão de Familiares de Mortos e Desaparecidos Políticos de São Paulo, o Centro pela Justiça e pelo Direito Internacional-Cejil e a Human Rights Watch/Américas, em 1996, apresentaram à Comissão Interamericana de Direitos Humanos uma petição alegando a violação, por parte do Estado brasileiro, de diversos direitos previstos na Convenção Americana de Direitos Humanos.

O Decreto $\mathrm{n}^{\circ} 678$, de 6 de novembro de 1992, promulgou a Convenção Americana sobre Direitos Humanos, também conhecida por Pacto de São José da Costa Rica. Em verdade, tal Convenção assegura uma série de direitos civis e políticos, gerando para o Estado o dever de dar efetividade à Convenção. Com o fim de fiscalizar as disposições pactuadas, o tratado internacional prevê dois mecanismos distintos: a Comissão Interamericana de Direitos Humanos e a Corte Interamericana de Direitos Humanos. A primeira faz recomendações aos Estados, solicita informações, aponta medidas a serem adotadas, prepara estudos e submete relatórios anuais à Assembleia Geral da Organização dos Estados Americanos. As comunicações de violação à Convenção podem ser "encaminhadas por indivíduo ou grupo de indivíduos, ou ainda entidade não governamental",111, entretanto, deve haver "o prévio esgotamento dos recursos internos - salvo no caso de injustificada demora processual, ou no caso de a legislação doméstica não prover o devido processo legal." ${ }^{112}$ Se a Comissão Interamericana de Direitos Humanos, após analisar o mérito, não lograr

\footnotetext{
${ }^{111}$ PIOVESAN, Flávia. Introdução ao sistema interamericano de proteção dos direitos humanos: a Convenção Americana de Direitos Humanos. In: GOMES, Luiz Flávio; PIOVESAN, Flávia (Org.). O Sistema Interamericano de Proteção dos Direitos Humanos e o Direito Brasileiro. São Paulo: Revista dos Tribunais, 2000. p. 36

112 Ibid. p. 37-38
} 
êxito na solução do conflito existente entre denunciante e Estado, a questão poderá ser remetida à Corte Interamericana de Direitos Humanos, órgão jurisdicional do sistema interamericano de direitos humanos que analisam possíveis violações da Convenção Americana. A jurisdição contenciosa da Corte está limitada aos Estados que reconheçam expressamente, determinando "a adoção de medidas que se façam necessárias à restauração do direito então violado. [...] A decisão da Corte tem força jurídica vinculante e obrigatória, cabendo ao Estado seu imediato cumprimento."113 O Brasil, por meio do Decreto Legislativo no 89, de 3 de dezembro de 1998, reconheceu a jurisdição da Corte Interamericana de Direitos Humanos "para fatos a partir do reconhecimento" $" 114$.

Assim, foram realizadas audiências em Washington, através das quais representantes e familiares das vítimas puderam subsidiar a Comissão com informações e documentos, que admitiu o caso em 2001. Em 31 de outubro de 2008, foi aprovado o Relatório de Mérito $n^{\circ}$ 91/08, concluindo que o Estado brasileiro deixou de investigar e punir os responsáveis pelos desaparecimentos forçados, além de os instrumentos de natureza civil não terem se mostrado suficientes para garantir o acesso à informação e localizar os corpos. Foi recomendada ao Brasil a adoção de medidas como a responsabilização penal dos responsáveis, a publicação de todas as informações estatais relacionados à Guerrilha do Araguaia, o emprego de esforços na localização dos corpos e a criação de cursos educacionais sobre direitos humanos nas Forças Armadas. No dia 25 de março do ano de 2009, "em virtude da falta de implementação satisfatória das recomendações contidas no Relatório 91/08, [a Comissão] decidiu submeter o caso à

\footnotetext{
${ }^{113}$ PIOVESAN, Flávia. Introdução ao sistema interamericano de proteção dos direitos humanos: a Convenção Americana de Direitos Humanos. p. 45

${ }^{114}$ Decreto Legislativo ${ }^{\circ}$ 89, de 3 de dezembro de 1998.
} 
jurisdição da Corte Interamericana." ${ }^{115}$ Segundo a própria Comissão Interamericana de Direitos Humanos:

12. No Relatório de Mérito No. 91/08, a Comissão concluiu que o Estado brasileiro é responsável pela violação dos direitos ao reconhecimento da personalidade jurídica, à vida, à integridade pessoal, à liberdade pessoal, às garantias judiciais, à liberdade de pensamento e de expressão e à proteção judicial; em conexão com a obrigação geral de respeito e garantia dos direitos humanos e o dever de adotar disposições de direito interno, todos estabelecidos na Convenção Americana. Por outro lado, a CIDH estabeleceu a violação dos artigos I, XXV, XXVI, XVII e XVIII da Declaração Americana. ${ }^{116}$

\subsubsection{Da competência da Corte}

Na petição encaminhada à Corte Interamericana, reconheceu-se que “a demanda não se refere às violações da Declaração Americana encontradas pela CIDH nem aos fatos e violações que ocorreram com anterioridade à entrada em vigência da Convenção Americana" ${ }^{\text {"117 }}$. Entretanto, existem crimes permanentes - como o desaparecimento forçado e/ou a ocultação de cadáver - que persistiram após 10 de dezembro de 1998 -, além de que a própria omissão do Estado em garantir os direitos das vítimas constitui um atentado independente à Convenção Americana. Neste sentido, ao persistir na promoção da impunidade e desrespeitar os direitos das vítimas previstos no instrumento internacional, o Brasil segue violandoo. Neste sentido, não há que se questionar a sua competência para apreciar o caso em tela. Cite-se, a título de esclarecimento, a posição dos Procuradores

\footnotetext{
115 COMISSÃO INTERAMERICANA DE DIREITOS HUMANOS. Demanda perante a Corte Interamericana de Direitos Humanos, Caso 11.552 - Julia Gomes Lund e outros (Guerrilha do Araguaia) Contra a República Federativa do Brasil. Revista anistia política e justiça de transição: Ministério da Justiça. Brasília, n. 2, p. 385, jul./dez. 2009.

${ }^{116}$ COMISSÃO INTERAMERICANA DE DIREITOS HUMANOS. Demanda perante a Corte Interamericana de Direitos Humanos, Caso 11.552 - Julia Gomes Lund e outros (Guerrilha do Araguaia) Contra a República Federativa do Brasil. p. 378

117 COMISSÃO INTERAMERICANA DE DIREITOS HUMANOS. Demanda perante a Corte Interamericana de Direitos Humanos, Caso 11.552 - Julia Gomes Lund e outros (Guerrilha do Araguaia) Contra a República Federativa do Brasil. p. 378
} 
da República Marlon Alberto Weichert e Eugênia Augusta Gonzaga

Fávero:

[...] mesmo após o reconhecimento da jurisdição da Corte Interamericana de Direitos Humanos permaneceu a omissão em apurar, investigar e punir crimes contra a humanidade consumados durante a ditadura militar.

Ademais, há alguns crimes de natureza permanentes, como os seqüestros de pessoas que ainda se encontram desaparecidas e as ocultações de cadáveres, cuja data final da própria consumação pode se situar após esse reconhecimento da jurisdição da Corte.

[...]

Destarte, em que pese os ilícitos aqui apontados terem ocorrido (ou tido a consumação iniciada) antes da ratificação da Convenção Americana de Direitos Humanos pelo Brasil, bem como previamente ao reconhecimento da jurisdição da Corte Interamericana de Direitos Humanos, enquanto perdurar a situação de impunidade por omissão na investigação e punição desses delitos, estar-se-á violando os deveres fixados nos artigos $1.1,2^{\circ}$ e 25.1 da Convenção, assim como o previsto no artigo $8^{\circ} .^{118}$

Divergente não é o entendimento da própria Corte. No célebre Caso Almonacid Arellano x Chile, que teve como pano de fundo uma execução extrajudicial atribuída à ditadura de Pinochet, o Estado chileno terminou condenado "não pela prática em si do homicídio, mas sim pela ausência de providências posteriores destinadas à cabal apuração do ocorrido, responsabilização dos envolvidos e reparação de danos aos familiares."119

\subsubsection{Dos crimes contra a humanidade}

De qualquer sorte, a Comissão afirmou que estes fatos constituem crimes de lesa-humanidade, portanto imprescritíveis e insuscetíveis de anistia. $\mathrm{O}$ conceito de crime contra a humanidade já existe desde a Primeira Guerra Mundial, contudo, apenas depois da Segunda Guerra Mundial - em

\footnotetext{
118 FÁVERO, Eugênia Augusta Gonzaga; WEICHERT, Marlon Alberto. Texto base sobre responsabilidade criminal. Disponível em <http://www.prr3.mpf.gov.br/component/option,com_remository/Itemid,68/func,download/id,161 5/chk,1835da563757fe01537d244ee4e80bbb/no_html,1/>. Acesso em 12 out. 2010.

119 FÁVERO, Eugênia Augusta Gonzaga; WEICHERT, Marlon Alberto. Texto base sobre responsabilidade criminal.
} 
razão das barbaridades nazistas que não eram puníveis pelo ordenamento jurídico interno - houve as primeiras responsabilizações, reconhecidas e formalizadas pelo artigo 6(c) do Estatuto do Tribunal de Nuremberg, na Alemanha. "Note-se que, já naquele tempo, não se tratou da instituição de tipo penal para aplicação retroativa, mas sim da consolidação escrita do conceito construído desde o início do século no direito internacional" ${ }^{\text {"120 }}$. Tal conceito foi ratificado em 1946 pela Assembleia Geral da Organização das Nações Unidas ${ }^{121}$, confiando à Comissão de Direito Internacional a elaboração de um documento - aprovado em 1950 - formalizando a costumeira determinação de que, quando o direito interno de um país for insuficiente para responsabilizar criminosos de Estado, o direito internacional deverá ser utilizado para garantir o direito à Justiça. Inúmeros outros instrumentos podem ser utilizados para definir os crimes de lesahumanidade, desde o Estatuto do Tribunal Penal Internacional para os Crimes cometidos na ex-Iugoslávia (TPII), instituído pelas Resoluções $\mathrm{n}^{\circ} \mathrm{s}$ 808 e 827 do Conselho de Segurança da Organização das Nações Unidas que, de acordo com a Carta da ONU, tem poder para editar resoluções vinculantes aos demais membros da Organização -, ao Estatuto de Roma, ratificado pelo Brasil através do Decreto $\mathrm{n}^{\circ} 4.388$, de 25 de setembro de 2002. Sobre os crimes contra a Humanidade, invoque-se a didática definição dada pelo International Center for Transitional Justice:

Poderia considerar-se, então, à luz tanto dos Princípios de Nüremberg de 1950, como do Estatuto de Roma e da jurisprudência dos tribunais penais internacionais e mistos, que se está diante de um crime de lesa-humanidade quando: i) é cometido um ato inumano em sua natureza e caráter, o qual produz um grande sofrimento na vítima ou que causa danos à sua integridade física e/ou saúde física e/ou mental, ii) quando esse ato é cometido como parte de um ataque sistemático ou generalizado; iii) quando esse ataque responde a uma política que - como se

\footnotetext{
120 FÁVERO, Eugênia Augusta Gonzaga; WEICHERT, Marlon Alberto. Texto base sobre responsabilidade criminal.

${ }^{121}$ Resolução $n^{\circ}$ 95, de 11 de dezembro de 1946.
} 
verá adiante - não necessariamente deve haver sido adotada de maneira formal; e iv) quando o ataque é dirigido contra população civil. ${ }^{122}$

\subsubsection{Da obrigação de investigar}

Logo, "a obrigação de investigar e processar penalmente os crimes contra a humanidade é uma norma jus cogens, que não nasce com essa Convenção senão que está reconhecida nela". ${ }^{123}$ Não há que se questionar a força normativa do costume no direito internacional, especialmente quando vinculado à proteção dos direitos humanos. Aliás, o "tratado e o costume possuem o mesmo valor, sem que um tenha primazia sobre o outro." 124 "Não necessariamente os tratados internacionais consagram novas regras de Direito Internacional. Por vezes, acabam por codificar regras preexistentes, consolidadas pelo costume internacional” ${ }^{, 25}$. O costume obriga os Estados ao respeito de algumas normas básicas de direitos humanos, e impedir a impunidade de crimes contra a Humanidade é uma delas. Tais crimes são tão graves que não se restringem ao plano interno, ofendendo também a ordem jurídica internacional. Quando, por exemplo, o Estado se organiza e passa a perseguir indiscriminadamente parcela de sua população civil, seja por razões políticas, raciais ou religiosas, toda a comunidade universal é atingida, exigindo, portanto, a punição dos responsáveis, considerando para isso tais crimes imprescritíveis e insuscetíveis de anistia - como acontece desde a II Guerra Mundial. A preocupação da ordem internacional é impedir a impunidade decorrente do ordenamento jurídico interno de cada

\footnotetext{
122 INTERNATIONAL CENTER FOR TRANSITIONAL JUSTICE. Parecer técnico sobre a natureza dos crimes de lesa-humanidade, a imprescritibilidade de alguns delitos e a proibição de anistias. Revista anistia política e justiça de transição: Ministério da Justiça. Brasília, n. 1, p. 360, jan./jun. 2009.

${ }^{123}$ COMISSÃO INTERAMERICANA DE DIREITOS HUMANOS. Demanda perante a Corte Interamericana de Direitos Humanos, Caso 11.552 - Julia Gomes Lund e outros (Guerrilha do Araguaia) Contra a República Federativa do Brasil. p. 451

${ }^{124}$ MELLO, Celso D. de Albuquerque. Curso de Direito Internacional Público. V. 1. 14 a ed.. Rio de Janeiro: Renovar, 2002. p. 288

${ }^{125}$ PIOVESAN, Flávia. Direitos Humanos e o Direito Constitucional Internacional. $11^{\text {a }}$ ed. São Paulo: Saraiva, 2010. p. 44
} 
país, elaborado muitas vezes pelos próprios criminosos, ou ainda de uma provável prescrição, tendo em que as ditaduras sustentam-se no poder por tempo indeterminado. Para o professor Celso D. de Albuquerque Mello: "As noções de crime internacional, norma de jus cogens e obrigação erga omnes visam a proteger os interesses comuns da sociedade internacional. [...] Todo crime internacional é definido em norma de jus cogens ${ }^{\text {} 126}$.

O costume encontra-se expressamente reconhecido na Convenção de Viena sobre o Direito dos Tratados, de 26 de maio de 1969, incorporada ao direito interno através do Decreto Legislativo n 496, de 17 de julho de 2009:

\footnotetext{
Artigo 38

Regras de um Tratado Tornadas Obrigatórias para Terceiros Estados por Força do Costume Internacional

Nada nos artigos 34 a 37 impede que uma regra prevista em um tratado se torne obrigatória para terceiros Estados como regra consuetudinária de Direito Internacional, reconhecida como tal.
}

O Brasil, ao ratificar a Convenção de Viena sobre o Direito dos Tratados, não fez qualquer reserva ao dispositivo, internalizando - o que sequer era necessário - a força normativa do costume internacional. De qualquer forma, o Supremo Tribunal Federal já reconhecia o direito consuetudinário internacional como fonte normativa, afirmando em 1973 antes da ratificação da Convenção de Viena sobre o Direito dos Tratados -, por exemplo, que a imunidade de jurisdição aos Estados estrangeiros seria válida "no Brasil por força do costume internacional e impedia o exercício do direito de ação regulado no direito interno (RE 56.466/DF, Rel. Min. BILAC PINTO, Pleno, RTJ 66/727)."127

Como consectário do reconhecimento da força normativa do jus cogens, "[a] tortura é crime de lesa-humanidade, considerado imprescritível

\footnotetext{
${ }^{126}$ MELLO, Celso D. de Albuquerque. Curso de Direito Internacional Público. p. 81

127 FÁVERO, Eugênia Augusta Gonzaga; WEICHERT, Marlon Alberto. Anistia, tortura, república e democracia.
} 
pela ordem internacional. Demanda do Estado o dever de investigar, processar, punir e reparar a violação perpetrada" ${ }^{, 28}$. Deve ser reforçado que, mesmo não se reconhecendo a aptidão do costume internacional para produzir tais efeitos na ordem jurídica interna - e por consequência se despreze a imprescritibilidade dos crimes contra a Humanidade -, o Caso Guerrilha do Araguaia x Brasil não se altera substancialmente, tendo em vista que continuam desaparecidos cerca de 70 militantes do PC do B. Deste modo, a questão versa sobre sequestros e/ou ocultações de cadáveres, crimes permanentes, "quando a consumação se prolonga no tempo"129. Necessariamente, não há que se falar em incompetência da Corte ou prescrição para tais delitos.

\subsubsection{Dos direitos violados}

Para a CIDH, o desaparecimento forcado constitui grave violação aos artigos 4.1 (direito à vida), 5 (direito à integridade pessoal) e 7 (direito à liberdade pessoal), conjugados ao artigo 1.1 (obrigação de respeitar e garantir direitos), todos da Convenção Americana. Não obstante, a Comissão entendeu que o artigo 5 (direito à integridade física) foi igualmente violado em relação aos familiares dos desaparecidos, pois "geram sofrimento e angústia [...] [a] falta de notícias sobre o paradeiro de seus entes queridos. A violação da integridade psíquica e moral dos familiares é uma conseqüência direta" ${ }^{" 130}$. A afirmação se justifica na medida em que o artigo 5 prevê o direito à integridade pessoal, exprimindo tanto a integridade física quanto a psíquica e moral, verificando-se que as

\footnotetext{
${ }^{128}$ PIOVESAN, Flávia. Direito internacional dos direitos humanos e lei de anistia: o caso brasileiro. Revista anistia política e justiça de transição. Brasília: Ministério da Justiça, n. 2, p. 181, jul./dez. 2009.

${ }^{129}$ MIRABETE, Julio Fabbrini. Manual de Direito Penal. $23^{a}$ ed. São Paulo: Atlas, 2006. p. 118

${ }^{130}$ COMISSÃO INTERAMERICANA DE DIREITOS HUMANOS. Demanda perante a Corte Interamericana de Direitos Humanos, Caso 11.552 - Julia Gomes Lund e outros (Guerrilha do Araguaia) Contra a República Federativa do Brasil. p. 443
} 
últimas continuam sendo afetadas pela impunidade e pela falta de informações oficiais a respeito da Guerrilha do Araguaia. A CIDH sustentou também que a aplicação da Lei de Anistia, como vem sendo interpretada, viola os artigos 8 (garantias judiciais) e 25 (proteção judicial), impedindo que as vítimas do regime militar possam buscar seus direitos no Judiciário. A respeito do direito à proteção judicial, assim leciona Lucia Elena Arantes Ferreira Bastos, em seu livro Anistia - As Leis Internacionais e o Caso Brasileiro:

A compreensão, neste caso, é a de que, ao impedir o acesso aos procedimentos penais e/ou cíveis, as anistias também violam o direito à proteção judicial ou a um remédio efetivo, pois as reparações, normalmente, chegam sob a forma de uma compensação, mas também elas podem tomar a forma de acesso à verdade, responsabilização ou punição.

$\mathrm{O}$ direito à proteção judicial encontra-se previsto no art. 25 da Convenção Americana de Direitos Humanos, ao prever que toda pessoa tem direito a um recurso simples e rápido que a proteja contra atos que violem seus direitos fundamentais. Com base nesse artigo a Comissão Interamericana de Direitos Humanos já interpretou que, por meio da anistia, a Argentina havia violado esse direito das vítimas a um remédio efetivo. ${ }^{131}$

Neste sentido, a Comissão considerou o Brasil em mora também pela "ineficácia das ações de natureza não-penal impetradas sobre o presente caso até o momento" 132 . Em verdade, embora a Lei de Anistia não devesse interferir nas ações cíveis, estas têm se mostrado insuficientes para garantir o acesso à informação e à Justiça. Diante da falta de investigação dos fatos, até hoje não se sabe o que realmente ocorreu, tornando quase impossível a localização dos corpos. Os familiares, bem como toda a sociedade brasileira, têm o direito de conhecer a própria História e exigir a responsabilização dos autores de crimes contra a Humanidade, cujo alvo foi justamente a população civil. Em conclusão, a CIDH sustenta ainda a

\footnotetext{
${ }^{131}$ BASTOS, Lucia Elena Ferreira. Anistia - As Leis Internacionais e o Caso Brasileiro. Curitiba: Juruá, 2009. p. 96

${ }^{132}$ COMISSÃO INTERAMERICANA DE DIREITOS HUMANOS. Demanda perante a Corte Interamericana de Direitos Humanos, Caso 11.552 - Julia Gomes Lund e outros (Guerrilha do Araguaia) Contra a República Federativa do Brasil. p. 454
} 
violação aos artigos 3 (direito ao reconhecimento da personalidade jurídica) e 13 (liberdade de pensamento e expressão), tendo em vista a indefinição jurídica que toma conta da figura do desaparecido. Ao mesmo tempo em que não está vivo, também não se pode dizer que está morto. Nos termos da petição encaminhada à Corte Interamericana de Direitos Humanos:

207. Com base nas considerações anteriores, a Comissão estabeleceu no seu relatório de mérito que o Estado brasileiro, ao adotar normas que restringiram indevidamente o acesso à informação sobre a Guerrilha do Araguaia, violou em detrimento dos familiares dos desaparecidos da Guerrilha do Araguaia e dos familiares de Maria Lucia Petit da Silva o artigo 13 da Convenção Americana, em relação com o dever previsto no artigo 2 do mencionado instrumento internacional.

[...]

214. Com efeito, o desaparecimento como violação de múltiplos direitos, procura e produz a anulação da personalidade jurídica da vítima. Como literalmente já foi indicado: "Tu não existes, não estás nem com os vivos nem com os mortos; a pessoa desaparecida desvanece-se para o mundo e o mundo também é desvanecido para ela.",133

\subsubsection{Dos pedidos}

Pediu-se à Corte Interamericana, então, que ordene o Estado brasileiro a "[a]dotar todas as medidas necessárias, a fim de que a Lei № 6.683/79 (Lei de Anistia) não continue representando um obstáculo para a persecução penal de graves violações de direitos humanos" ${ }^{\text {"134 }}$ cometidas na repressão à Guerrilha do Araguaia, publicando os resultados das investigações. Requereu-se também a abertura de todos os arquivos referentes ao conflito, possibilitando a localização dos corpos dos militantes desaparecidos. Por fim, foi pedido que a Corte condene o Brasil a “[i]mplementar, dentro de um prazo razoável, programas de educação em

\footnotetext{
${ }^{133}$ COMISSÃO INTERAMERICANA DE DIREITOS HUMANOS. Demanda perante a Corte Interamericana de Direitos Humanos, Caso 11.552 - Julia Gomes Lund e outros (Guerrilha do Araguaia) Contra a República Federativa do Brasil. p. 460

${ }^{134}$ COMISSÃO INTERAMERICANA DE DIREITOS HUMANOS. Demanda perante a Corte Interamericana de Direitos Humanos, Caso 11.552 - Julia Gomes Lund e outros (Guerrilha do Araguaia) Contra a República Federativa do Brasil. p. 474
} 
direitos humanos permanentes dentro das Forças Armadas brasileiras" ${ }^{\text {135 }}$, a "[o]utorgar uma reparação aos familiares das vítimas desaparecidas e da pessoa executada, que inclua o tratamento física e psicológico"136, e a "[t]ipificar no seu ordenamento interno o crime de desaparecimento forçado" ${ }^{\prime 137}$.

Nos dias 20 e 21 de maio de 2010, realizou-se, em São José da Costa Rica, audiência pública sobre Caso Guerrilha do Araguaia x Brasil, onde foram ouvidos os representantes das vítimas, testemunhas, peritos e representantes do Estado brasileiro. Sendo assim, a qualquer momento a Corte Interamericana de Direitos Humanos pode divulgar sua sentença de mérito no caso brasileiro.

\subsection{Da iminente sentença}

\subsubsection{Das possibilidades}

Passa-se, então, à análise das possíveis consequências da condenação do Estado brasileiro, uma vez que uma eventual absolvição não gerará maiores problemas teóricos ou práticos, tendo em vista que estará em conformidade com a decisão proferida pelo STF quando do julgamento da $\mathrm{ADPF}^{\circ}{ }^{\circ}$ 153. Por Entretanto, considerando a jurisprudência construída pela Corte Interamericana de Direitos Humanos até o momento, pode-se dizer que a improcedência da referida demanda é mais do que improvável. São inúmeros os julgados em que a Corte decidiu pela invalidade das leis de

\footnotetext{
135 COMISSÃO INTERAMERICANA DE DIREITOS HUMANOS. Demanda perante a Corte Interamericana de Direitos Humanos, Caso 11.552 - Julia Gomes Lund e outros (Guerrilha do Araguaia) Contra a República Federativa do Brasil. p. 475

${ }^{136}$ COMISSÃO INTERAMERICANA DE DIREITOS HUMANOS. Demanda perante a Corte Interamericana de Direitos Humanos, Caso 11.552 - Julia Gomes Lund e outros (Guerrilha do Araguaia) Contra a República Federativa do Brasil. p. 475

137 COMISSÃO INTERAMERICANA DE DIREITOS HUMANOS. Demanda perante a Corte Interamericana de Direitos Humanos, Caso 11.552 - Julia Gomes Lund e outros (Guerrilha do Araguaia) Contra a República Federativa do Brasil. p. 475
} 
anistia para crimes contra a humanidade. O primeiro destes foi o Caso Barrios Altos x Peru, envolvendo o massacre de quinze pessoas em 1991, durante a luta contra a subversão desenvolvida pelo governo de Alberto Fujimori: "Concluiu a Corte que as leis de 'autoanistia' perpetuam a impunidade, propiciam uma injustiça continuada, impedem às vítimas e aos seus familiares o acesso à justiça e o direito de conhecer a verdade" ${ }^{\text {"138. }}$. Neste mesmo sentido, vieram as decisões do já mencionado Caso Almonacid Arellano $x$ Chile e do Caso La Cantuta $x$ Peru, entre outros.

Quais seriam as implicações de uma condenação, tendo em vista que o Supremo Tribunal Federal já decidiu internamente sobre a Lei de Anistia? Como o Estado brasileiro reagiria às determinações da Corte? Não há elementos para uma resposta segura. Contudo, Lucia Elena Arantes Ferreira Bastos lembra que em 1993 a CIDH "submeteu à Corte Interamericana a solicitação de parecer consultivo sobre quais seriam os efeitos jurídicos de uma lei que viola parte da Convenção Americana de Direitos Humanos" ${ }^{\text {,139 }}$. Nesta ocasião,

[e]m sua primeira manifestação formal na jurisdição consultiva da Corte Interamericana que se deu nesse caso, o Brasil respondeu que o âmago do problema seria resolvido pela teoria que cada Estado seguia em matéria de hierarquia de leis. [...]

Quanto à segunda parte da questão, a respeito da responsabilidade dos funcionários, o Brasil argumentou que, sob o aspecto nacional, os agentes e funcionários do Estado devem submeter-se às ordens da Constituição, não podendo invocar convenções internacionais em que o Estado seja parte para descumpri-la. ${ }^{140}$

Tal posicionamento reflete a concepção dualista, separando a ordem jurídica interna da internacional, na qual os instrumentos internacionais só têm validade se e quando incorporados ao direito interno, diferentemente da teoria monista. "Em apertada síntese, caracteriza o monismo a possibilidade

\footnotetext{
${ }^{138}$ PIOVESAN, Flávia. Temas de Direitos Humanos. $4^{\text {a }}$ ed. São Paulo: Saraiva, 2010. p. 459

${ }^{139}$ BASTOS, Lucia Elena Ferreira. Anistia - As Leis Internacionais e o Caso Brasileiro. Curitiba: Juruá, 2009. p. 265

${ }^{140}$ BASTOS, Lucia Elena Ferreira. Anistia - As Leis Internacionais e o Caso Brasileiro. p. 266
} 
de aplicação direta e automática das normas de Direito Internacional pelos agentes do Poder estatal" ${ }^{141}$. Na toada do que manifestou o Estado brasileiro, qualquer conflito entre a Convenção Americana e uma lei ordinária se resolveria com lastro no critério hierárquico dos diplomas legais envolvidos. Assim, para um melhor entendimento da questão, far-seá um breve passeio pelo debate sobre a força normativa atribuída aos tratados de direitos humanos no direito brasileiro.

\subsubsection{Da hierarquia dos tratados}

Em 1977, o Supremo Tribunal Federal, quando do julgamento do Recurso Extraordinário $\mathrm{n}^{\circ} 80.004$, decidiu pela paridade hierárquica entre os tratados internacionais e as leis federais. Neste raciocínio, estando os mesmos em planos jurídicos idênticos, qualquer aparente antinomia resolver-se-ia pelo critério cronológico, podendo uma lei federal revogar um tratado internacional. O cenário foi totalmente alterado pela Constituição da República de 1988 , tendo em vista o advento do art. $5^{\circ}$, § $2^{\circ}$, que dispõe:

$\S 2^{\circ}$ - Os direitos e garantias expressos nesta Constituição não excluem outros decorrentes do regime e dos princípios por ela adotados, ou dos tratados internacionais em que a República Federativa do Brasil seja parte.

Sendo assim, parte da doutrina defende, desde a edição da Constituição de 1988, que estariam constitucionalmente protegidos os direitos previstos em tratados de direitos humanos que o Brasil seja signatário, em consonância com o art. $4^{\circ}$, II, que estabelece a prevalência dos direitos humanos nas relações internacionais da República Federativa do Brasil. Para Flávia Piovesan, “a contrario sensu, a Carta de 1988 está a

\footnotetext{
141 RAMOS, André de Carvalho. Responsabilidade internacional por violação de direitos humanos: Seus elementos, a reparação devida e sanções possíveis: Teoria e prática do Direito Internacional. Rio de Janeiro: Renovar, 2004. p. 117
} 
incluir, no catálogo de direitos constitucionalmente protegidos, os direitos enunciados nos tratados internacionais em que o Brasil seja parte." ${ }^{142}$ Este entendimento parece ser o mais razoável, uma vez que, do contrário, perdese a razão de tal dispositivo estar embutido justamente no art. $5^{\circ}$ da Constituição Federal. Ademais, como os direitos fundamentais devem ser interpretados ampliativamente, é forçoso reconhecer que a norma constitucional não fez qualquer menção a respeito de uma suposta hierarquia infraconstitucional. "Os direitos enunciados nos tratados de direitos humanos de que o Brasil é parte integram, portanto, o elenco dos direitos constitucionalmente consagrados." ${ }^{143}$ Quanto aos demais tratados, é pacífico que estes continuam tendo hierarquia infraconstitucional, como evidencia o art. 102, III, $b$ da Constituição Federal, ao conferir ao Supremo Tribunal Federal a competência para julgar "as causas decididas em única ou última instância, quando a decisão recorrida declarar a inconstitucionalidade de tratado ou lei federal".

Não obstante o comando dado pela nova ordem constitucional, em 1995 a tese da paridade com as leis federais foi mantida pelo Supremo Tribunal Federal, quando do julgamento de um habeas corpus $\left(\mathrm{HC} \mathrm{n}^{\circ}\right.$ 72.131/RJ) relativo à prisão civil por dívida do depositário infiel, admitida pelo art. $5^{\circ}$, LXVII da Constituição Federal e vedada pelo art. $7^{\circ}$ (7) da Convenção Americana de Direitos Humanos. $\mathrm{Na}$ ocasião, restaram vencidos os Ministros Marco Aurélio, Carlos Velloso e Sepúlveda Pertence, prevalecendo o entendimento de que a prisão seria válida, uma vez que o tratado internacional não poderia sobrepor-se à Constituição.

Firmaram-se na doutrina quatro correntes distintas acerca da hierarquia dos tratados de direitos humanos na nova ordem constitucional: enquanto uns defendem a natureza constitucional, com base no art. $5^{\circ}, \S 2^{\circ}$ da Carta Maior, outros defendem a paridade com as leis federais. A terceira

\footnotetext{
${ }^{142}$ PIOVESAN, Flávia. Direitos Humanos e o Direito Constitucional Internacional. p. 52

${ }^{143}$ PIOVESAN, Flávia. Direitos Humanos e o Direito Constitucional Internacional. p. 52
} 
"sustenta que os tratados de direitos humanos têm hierarquia supraconstitucional, enquanto a outra corrente defende a hierarquia infraconstitucional, mas supralegal, dos tratados de direitos humanos."144 Neste cenário, com o intuito de pôr fim às tantas polêmicas referentes à hierarquia dos tratados de direitos humanos, a Emenda Constitucional $n^{\circ} 45$, de 8 de dezembro de 2004 , ao acrescentar o $\S 3^{\circ}$ ao art. $5^{\circ}$, equiparou às EC os "tratados e convenções internacionais sobre direitos humanos que forem aprovados, em cada Casa do Congresso Nacional, em dois turnos, por três quintos dos votos dos respectivos membros". Por outro lado, a norma não tratou da hierarquia dos tratados incorporados antes da emenda constitucional $\mathrm{n}^{\mathbf{o}} 45$, de modo que parte da doutrina novamente se manifestou pela proteção hierarquia constitucional dos mesmos. ${ }^{145}$

O fato é que, com o advento do $\S 3^{\circ}$, houve uma reviravolta nos posicionamentos a respeito da hierarquia dos tratados internacionais de direitos humanos. Alterou-se, inclusive, a jurisprudência do Pretório Excelso acerca da possibilidade de prisão por dívida do depositário infiel, evidenciando um regime jurídico diferenciado para os tratados de direitos humanos. De acordo com a lição de Flávia Piovesan, em seu livro intitulado Direitos Humanos e o Direito Constitucional Internacional:

O impacto da inovação introduzida pelo art. $5^{\circ}$, $\S 3^{\circ}$, e a necessidade de evolução e atualização jurisprudencial foram também realçados no Supremo Tribunal Federal, quando do julgamento do RE 466.343, em 22 de novembro de 2006, em emblemático voto proferido pelo Ministro Gilmar Ferreira Mendes, ao destacar: “(...) a reforma acabou por ressaltar o caráter especial dos tratados de direitos humanos em relação aos demais tratados de reciprocidade entre Estados pactuantes, conferindo-lhes lugar privilegiado no ordenamento jurídico. (...) a mudança constitucional ao menos acena para a insuficiência da tese da legalidade ordinária dos tratados já ratificados pelo Brasil, a qual tem sido preconizada pela jurisprudência do Supremo Tribunal Federal desde o remoto julgamento do RE $n$. 80.004/SE, de relatoria do Ministro Xavier de Albuquerque (julgado em 1.6.1977; DJ 29.12.1977) e encontra respaldo em largo repertório de casos julgados após o advento da Constituição de 1988. (...) Tudo indica, portanto, que a jurisprudência do Supremo Tribunal Federal, sem sombra de dúvidas, tem de

\footnotetext{
${ }^{144}$ PIOVESAN, Flávia. Direitos Humanos e o Direito Constitucional Internacional. p. 68

${ }^{145}$ PIOVESAN, Flávia. Direitos Humanos e o Direito Constitucional Internacional. p. 72
} 
ser revisitada criticamente. (...) Assim, a premente necessidade de se dar efetividade à proteção dos direitos humanos nos planos interno e internacional torna imperiosa uma mudança de posição quanto ao papel dos tratados internacionais sobre direitos na ordem jurídica nacional. É necessário assumir uma postura jurisdicional mais adequada às realidades emergentes em âmbitos supranacionais, voltadas primordialmente à proteção do ser humano. (...) Deixo acentuado, também, que a evolução jurisprudencial sempre foi uma marca de qualquer jurisdição constitucional. (...) Tenho certeza de que o espírito desta Corte, hoje, mais do que nunca, está preparado para essa atualização jurisprudencial". Por fim, concluiu o Ministro pela supralegalidade dos tratados de direitos humanos. ${ }^{146}$

O Ministro Gilmar Mendes, como se viu, refutou a tese da paridade entre os tratados de direitos humanos e as leis federais, invocando a supralegalidade dos primeiros. Já o Ministro Celso de Mello, apesar de também descartar a paridade, sustentou a hierarquia constitucional dos tratados de direitos humanos:

Ao avançar no enfrentamento do tema, merece ênfase o primoroso voto do Ministro Celso de Mello a respeito do impacto do art. $5^{\circ}, \S 3^{\circ}$, e da necessidade de atualização jurisprudencial do Supremo Tribunal Federal, quando do julgamento do HC 87.585-8, em 12 de março de 2008, envolvendo a problemática da prisão civil do depositário infiel. [...]

É sob esta perspectiva, inspirada na lente ex parte populi e no valor ético fundamental da pessoa humana, que o Ministro Celso de Mello reavaliou seu próprio entendimento sobre a hierarquia dos tratados de direitos humanos, para sustentar a existência de um regime jurídico misto, baseado na distinção entre os tratados tradicionais e os tratados de direitos humanos, conferindo aos últimos hierarquia constitucional. Neste sentido, argumentou: "Após longa reflexão sobre o tema, (...), julguei necessário reavaliar certas formulações e premissas teóricas que me conduziram a conferir aos tratados internacionais em geral (qualquer que fosse a matéria neles veiculadas), posição juridicamente equivalente à das leis ordinárias. As razões invocadas neste julgamento, no entanto, convencem-me da necessidade de se distinguir, para efeito de definição de sua posição hierárquica em face do ordenamento positivo interno, entre as convenções internacionais sobre direitos humanos (revestidas de 'supralegalidade', como sustenta o eminente Ministro Gilmar Mendes ou impregnadas de natureza constitucional, como me inclino a reconhecer) e tratados internacionais sobre as demais matérias (compreendidos estes numa estrita perspectiva de paridade normativa com as leis ordinárias). [...]"147

${ }^{146}$ PIOVESAN, Flávia. Direitos Humanos e o Direito Constitucional Internacional p. $74-75$
${ }^{147}$ PIOVESAN, Flávia. Direitos Humanos e o Direito Constitucional Internacional. p. 76 
De qualquer forma, o fato inequívoco é que, ao negar provimento ao RE $n^{\circ} 466.343$, o Supremo Tribunal Federal declarou a prevalência da Convenção Americana de Direitos Humanos sobre uma norma constitucional, dividindo-se entre as teses da supralegalidade e da constitucionalidade dos tratados de direitos humanos, sendo a primeira majoritária. Novamente, invoque-se o esclarecimento de Flávia Piovesan:

Em 3 de dezembro de 2008, o Supremo Tribunal Federal, por unanimidade, negou provimento ao Recurso Extraordinário n. 466.343, estendendo a proibição da prisão civil por dívida à hipótese de alienação fiduciária em garantia, com fundamento na Convenção Americana de Direitos Humanos (art. $7^{\circ}, \S 7^{\circ}$ ). Tal dispositivo proíbe a prisão civil por dívida, salvo no caso de inadimplemento de obrigação alimentícia. Diversamente, a Constituição Federal de 1988, no art. $5^{\circ}$, LXVII, embora estabeleça a proibição da prisão civil por dívida, excepciona as hipóteses do depositário infiel e do devedor de alimentos. [...] Convergiu, ainda, o Supremo Tribunal Federal em conferir aos tratados de direitos humanos um regime especial e diferenciado, distinto do regime jurídico aplicável aos tratados tradicionais. Todavia, divergiu no que se refere especificamente à hierarquia a ser atribuída aos tratados de direitos humanos, remanescendo dividido entre a tese da supralegalidade e a tese da constitucionalidade dos tratados de direitos humanos, sendo a primeira tese a majoritária, vencidos os Ministros Celso de Mello, Cesar Peluso, Ellen Grace e Eros Grau, que conferiam aos tratados de direitos humanos status constitucional. ${ }^{148}$

\subsubsection{Convenção Americana $x$ Lei de Anistia}

O estudo acerca da hierarquia normativa dos tratados internacionais é imprescindível para "apurar qual a lei aplicável diante de um conflito entre as disposições de um tratado de direitos humanos e o conteúdo de uma lei interna, em especial, de uma lei de anistia em branco."149 Caso o Estado brasileiro seja condenado pela Corte Interamericana de Direitos Humanos, restará evidenciado o conflito existente entre uma lei federal (Lei de Anistia) e a Convenção Americana de Direitos Humanos, devendo notadamente prevalecer o tratado internacional de direitos humanos em desfavor da lei ordinária. Ademais, mesmo que se adotasse a vetusta tese da

\footnotetext{
${ }^{148}$ PIOVESAN, Flávia. Direitos Humanos e o Direito Constitucional Internacional. p. 77

${ }^{149}$ BASTOS, Lucia Elena Ferreira. Anistia - As Leis Internacionais e o Caso Brasileiro. p. 219
} 
paridade entre os tratados de direitos humanos e as leis federais, a aparente antinomia seria solucionada através da aplicação do critério cronológico, novamente em benefício do instrumento internacional. Neste sentido, Lucia Elena Ferreira Bastos:

Se fosse aplicado somente o critério cronológico e se o caso fosse de paridade hierárquica entre lei interna e disposição internacional (o que já ficou comprovado não ser mais o enquadramento desde a EC 45/04), seguindo o pressuposto de que a lei posterior revoga a lei anterior, deveria prevalecer o direito a um julgamento justo (art. $8^{\circ}$ ) e o direito à proteção judicial (art. 25), previstos na Convenção Americana de Direitos Humanos que foi ratificada pelo Brasil em 1992, por meio do Decreto de promulgação 678, de 06.11.1992, em detrimento da Lei 6.683, de 28.08.1979 (Lei de Anistia), que impede a persecução criminal pelas violações dos direitos humanos ocorridas no período compreendido entre 02.09.1961 e 15.08.1979.

Essa argumentação recebe ainda mais força, se for considerado que se está diante de duas normas conflitantes de distinta hierarquia legal (emenda constitucional versus lei ordinária federal), de acordo com a estipulação conjunta dos $\S \S 1^{\circ}, 2^{\circ} \mathrm{e}$ $3^{\circ}$ do art. $5^{\circ}$ da Constituição Federal de 1988, pelo fato de a Convenção Americana de Direitos Humanos possuir status constitucional, há que se dar prevalência às suas disposições (arts. $8^{\circ}$ e 25 ) revogando-se a lei ordinária que lhe é contrária. ${ }^{150}$

Por fim, há um último método a ser utilizado na resolução de conflitos entre tratados de direitos humanos e leis internas. "E o critério a ser adotado se orienta pela escolha da norma mais favorável à vítima."151 Tal princípio está, inclusive, positivado no art. 29 da Convenção Americana de Direitos Humanos, e significa que na "vigência simultânea de vários sistemas normativos [...], em matéria de diretos humanos, deve ser aplicado aquele que melhor protege o ser humano." 152 Em suma, em caso de conflito, deve prevalecer a "norma que melhor e mais eficazmente proteja a dignidade humana." ${ }^{153}$ Neste caso, parece claro que também devem prevalecer os direitos das vítimas, previstos na Convenção Americana de

\footnotetext{
${ }^{150}$ BASTOS, Lucia Elena Ferreira. Anistia - As Leis Internacionais e o Caso Brasileiro. p. 224

${ }^{151}$ PIOVESAN, Flávia. Direitos Humanos e o Direito Constitucional Internacional. p. 104

${ }^{152}$ COMPARATO, Fábio Konder. A Afirmação Histórica dos Direitos Humanos. $4^{\mathrm{a}}$ ed. São Paulo: Saraiva, 2005. p. 363

${ }^{153}$ BASTOS, Lucia Elena Ferreira. Anistia - As Leis Internacionais e o Caso Brasileiro. p. 226
} 
Direitos Humanos, uma vez que protegem muito mais a dignidade humana do que a impunidade de crimes contra a humanidade.

\subsubsection{Do cumprimento}

Enfim, em caso de condenação pela Corte Interamericana de Direitos Humanos, restará ao Estado brasileiro executar a sentença de procedência, uma vez que, por meio do Decreto Legislativo $\mathrm{n}^{\circ}$ 89, de 3 de dezembro de 1998, o Brasil reconheceu expressamente a jurisdição da Corte, "tendo sua decisão força jurídica vinculante e obrigatória." ${ }^{154}$ Ademais, como se viu, em um eventual conflito entre a CADH e a Lei de Anistia, o instrumento internacional prevalece qualquer que seja o critério adotado para solucionar a aparente antinomia. Reforce-se, por ora, que a condenação pelos desaparecimentos forçados e pelas ocultações de cadáveres, em especial, não necessariamente confrontará a Lei de Anistia e a decisão do Supremo Tribunal Federal em relação à mesma, haja vista que tais crimes se situam fora do lapso temporal abarcado pela referida lei.

Como assevera o art. 68 da Convenção Americana de Direitos Humanos, os "Estados-partes na Convenção comprometem-se a cumprir a decisão da Corte em todo caso em que forem partes." Consequentemente, "exige-se o cumprimento no sistema interamericano por parte do Estado das necessárias obrigações de fazer e não-fazer exigidas para que a vítima possa fazer valer seu direito violado." ${ }^{155}$ Neste sentido, a decisão da Corte Interamericana não anulará o julgamento da ADPF no 153 e nem revogará a Lei de Anistia, mas tão somente constituirá "obrigação internacional de resultado, ficando o Estado livre para escolher os meios internos para fazer

\footnotetext{
${ }^{154}$ PIOVESAN, Flávia. Direitos Humanos e o Direito Constitucional Internacional. p. 377 155 RAMOS, André de Carvalho. Processo internacional de direitos humanos: Análise dos sistemas de apuração de violações de direitos humanos e a implementação das decisões no Brasil. Rio de Janeiro: Renovar, 2002. p. 241
} 
cumprir o conteúdo de decisão judicial internacional."156 Como ensina André de Carvalho Ramos, em Processo Internacional de Direitos

Humanos, a respeito da execução de sentenças da Corte:

Advertimos que a lei brasileira não será revogada pela decisão internacional. Este não é o papel nem a função das deliberações internacionais de responsabilidade internacional do Estado por violação de direitos humanos, como já exposto anteriormente. $\mathrm{O}$ cumprimento pelo poder Judiciário da decisão internacional apenas suspende os efeitos da citada lei. A revogação da lei dependerá, é claro, da manifestação do Congresso e da edição de lei posterior, o que, é claro, não impede a imediata ação do ministério Público e da vítima para a exigência do cumprimento da decisão internacional.

[...]

Assim, em face do ordenamento jurídico brasileiro, as eventuais sentenças da Corte Interamericana de Direitos Humanos prescindem da rescisão ou mesmo declaração de nulidade de sentença judicial interna. No plano estritamente formal, a sentença internacional não rescinde nem reforma ato judicial interno, já que inexiste, como apontado, hierarquia funcional entre os tribunais internos e internacionais.

A sentença internacional, ao ser implementada internamente, suspende a eficácia do comando judicial interno, como decorrência implícita do próprio ato brasileiro de adesão à jurisdição obrigatória da Corte Interamericana de Direitos Humanos. ${ }^{157}$

Por conseguinte, caso o Estado brasileiro seja condenado a promover a persecução penal dos responsáveis pelos crimes contra a humanidade praticados durante o regime militar, deverão ser propostas pelo Ministério Público as respectivas ações penais, podendo ainda o Congresso Nacional optar pela revogação da Lei de Anistia:

De fato, caso a Corte Interamericana de Direitos Humanos tenha considerado ser violadora da Convenção a decisão de não-propositura de Ação Penal Pública (por violação do dever de combater a impunidade dos violadores de direitos humanos), por exemplo, caberá a revisão administrativa interna do arquivamento com base no decisum internacional, de modo a possibilitar a propositura da Ação Penal. ${ }^{158}$

\footnotetext{
156 RAMOS, André de Carvalho. Processo internacional de direitos humanos: Análise dos sistemas de apuração de violações de direitos humanos e a implementação das decisões no Brasil. Rio de Janeiro: Renovar, 2002. p. 311

${ }^{157}$ RAMOS, André de Carvalho. Processo internacional de direitos humanos. p. 351; 359

${ }^{158}$ RAMOS, André de Carvalho. Processo internacional de direitos humanos. p. 361
} 


\subsubsection{Da inadimplência}

No caso de não cumprimento da sentença da Corte, há “o nascimento de uma nova obrigação internacional secundária do Estado inadimplente, que seria a execução em boa-fé do julgamento" ${ }^{\text {"159 }}$. Persistindo a situação de negligência por parte do Estado, contudo, "a Convenção Americana não estabelece mecanismo específico para supervisionar o cumprimento das decisões da Comissão ou da Corte" ${ }^{" 160}$. O instrumento existente está no art. 65 da Convenção Americana de Direitos Humanos, possibilitando à Corte “a inclusão dos casos em que o Estado não tenha dado cumprimento a suas sentenças no seu relatório anual à Assembléia Geral da OEA."161 Ou seja, não há mecanismos que coajam o Estado ao cumprimento das decisões. "No âmbito da OEA, a obrigação de garantia de direitos humanos é inserida no artigo $5^{\circ}$ da Carta da OEA, mas não há nenhum procedimento expresso de edição de sanção por violação destes direitos protegidos." ${ }^{162}$ Corroborando esta deficiência do sistema interamericano, a verdade é que "não está claro nem a possibilidade de expulsão de um Estado como sanção pelo descumprimento de decisão da Corte Interamericana de Direitos

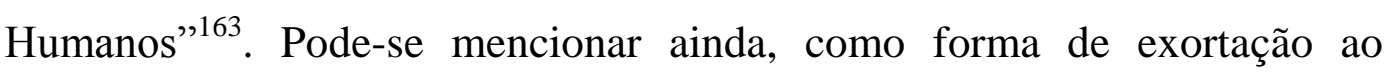
cumprimento das sentenças emanadas pelo sistema interamericano, a "pressão moral ou social, tanto por parte de Estados, quanto por parte da chamada opinião pública mundial [...], que é despida de força jurídica."164 Em verdade, deve-se dizer que o não cumprimento das decisões da Corte

\footnotetext{
${ }^{159}$ RAMOS, André de Carvalho. Processo internacional de direitos humanos. p. 313

${ }^{160}$ PIOVESAN, Flávia. Direitos Humanos e Justiça Internacional: Um estudo comparativo dos sistemas regionais europeu, interamericano e africano. São Paulo: Saraiva, 2007. p. 115

${ }^{161}$ RAMOS, André de Carvalho. O Diálogo das Cortes: O Supremo Tribunal Federal e a Corte Interamericana de Direitos Humanos. In: JUBILUT, Liliana Lyra; JUNIOR, Alberto do Amaral (org.). O STF e o Direito Internacional dos Direitos Humanos. São Paulo: Quartier Latin, 2009. p. 817

${ }_{162}^{162}$ RAMOS, André de Carvalho. Processo internacional de direitos humanos. p. 246

163 RAMOS, André de Carvalho. Responsabilidade internacional por violação de direitos humanos. p. 395

164 RAMOS, André de Carvalho. Responsabilidade internacional por violação de direitos humanos. p. 321-322
} 
Interamericana de Direitos Humanos é um comportamento impensável para um Estado que reconheceu sua jurisdição e atue de boa-fé nas relações internacionais. 


\section{CONCLUSÃO}

Era só mais uma dura

Resquício de ditadura

Mostrando a mentalidade

De quem se sente autoridade

Nesse tribunal de rua

Tribunal de Rua, O Rappa

Todos sabem que a ditadura outorgou a anistia que queria, ao tempo que quis. O Estado não pode promover a impunidade de crimes sexuais que ele mesmo praticou, ainda mais quando decorrentes de um assalto ao poder constitucionalmente eleito. Afirmar que a anistia - como fez o STF - foi resultado de um amplo acordo político para beneficiar torturadores e torturados significa legitimar o passado autoritário. Embora a classe política oposicionista - completamente descaracterizada pelas cassações, prisões e assassinatos - possa sim ter aceitado perdoar os torturadores em troca da volta de muitos filhos aos lares, não necessariamente por isto a Lei de Anistia possui validade. Quem compunha a classe política? Possuíam liberdade política para pactuar? Possuindo liberdade política, tinham legitimidade para fazer concessões em nome das vítimas? Parece claro que não. Independentemente de razões éticas ou morais, os fundamentos para a não concessão de anistia aos crimes contra a humanidade estão contidos no próprio ordenamento jurídico, e continuam sendo desprezados, por razões tão políticas e/ou morais quanto as que são imputadas aos defensores da responsabilização penal. Neste sentido, ao tentar encontrar respostas, este estudo deparou-se com infindáveis questões.

Em verdade, percebe-se que o sistema jurídico atual não está tão distante do que se tinha no período autoritário, quando o Poder Judiciário aderiu à chamada "Jurisdição de Segurança Nacional". Diferentemente de outros países latino-americanos, "nosso sistema judicial não sofreu rupturas 
institucionais em momentos de transição política." 165 Talvez por isto tais países tenham conseguido promover uma justiça de transição eficiente, enquanto nossos Tribunais têm enorme dificuldade em tratar do assunto. Uma das principais causas apontadas para esta dificuldade "enfrentada" pelo Judiciário seria, então, a judicialização do Estado de exceção diversamente também do que houve nos demais países latino-americanos. Cá no Brasil, com a maior institucionalização do golpe, os militares repartiram a responsabilidade com os outros poderes, de "forma bastante prejudicial à perspectiva de uma reforma judiciária democrática após o fim do regime militar."166 O Poder Judiciário integrou a máquina repressiva do regime. Paradoxalmente, como de certa forma foi possibilitada a discussão judicial da aplicação das leis de segurança nacional, muitas vezes serviu para garantir a vida de presos políticos, devido à habilidade de alguns advogados. Esta judicialização explicaria o número significativamente menor de vítimas da ditadura brasileira em comparação com a de países como Chile e Argentina. Logo, ao mesmo tempo em que minorou o número de vítimas, escancarou a aderência do Judiciário à ideologia da "segurança nacional", inviabilizando ainda hoje a implantação dos postulados da justiça de transição ${ }^{167}$. Paralelamente, o Executivo e o Legislativo empurram a discussão para o Poder Judiciário, afinal, procuram quase sempre se eximir das responsabilidades que possam levar à perda de apoio político ou eleitoral.

A decisão do Supremo Tribunal Federal, quando do julgamento da ADPF $\mathrm{n}^{\circ}$ 153, evidenciou esta posição. É inadmissível que o poder democrático seja assaltado, instalada uma ditadura, e, após o massacre de

\footnotetext{
165 SILVA, Alexandre Garrido da; VIEIRA, José Ribas. Justiça transicional, direitos humanos e a seletividade do ativismo judicial no Brasil. Revista anistia política e justiça de transição: Ministério da Justiça. Brasília, n. 2, p. 261, jul./dez. 2009.

${ }^{166}$ FILHO, Vladimir Brega; SANTOS, Roberto Lima. Os reflexos da "judicialização" da repressão política no Brasil no seu engajamento com os postulados da justiça de transição. Revista anistia política e justiça de transição: Ministério da Justiça. Brasília, n. 1, p. 173, jan./jun. 2009.

${ }^{167}$ FILHO, Vladimir Brega; SANTOS, Roberto Lima. Os reflexos da "judicialização" da repressão política no Brasil no seu engajamento com os postulados da justiça de transição. p. 159
} 
seus opositores, esta mesma ditadura possa autoanistiar-se. Significa que todas as barbaridades cometidas foram validadas. O STF, ao optar pela compatibilidade da autoanistia de crimes contra a humanidade face à Constituição Federal de 1988, afirmou para a sociedade que é legal usurpar o poder, perseguir, e, depois de concluída a empreitada, promover a impunidade das atrocidades praticadas. Note-se aqui que a declaração de incompatibilidade não implicaria necessariamente em punir os responsáveis pelos crimes da repressão, haja vista a existência de outras polêmicas barreiras a serem transpostas, a exemplo da prescrição. Ou seja, o Pretório Excelso, em sinceridade, poderia ter declarado a incompatibilidade de autoanistia para crimes tão graves, embora impedisse a persecução penal por conta da prescrição. Ao menos, a possibilidade de futuras autoanistias teria sido expressamente vedada, servindo de aviso para eventuais golpistas e/ou potenciais autores de crimes contra a humanidade. Ao validar a manobra ditatorial, o STF gerou insegurança para a sociedade civil e não desencorajou novas violações semelhantes, haja vista a possibilidade de se “anistiá-las". Enfim, o Supremo Tribunal Federal preferiu avisar à sociedade que perpetradores de crimes contra a humanidade podem sim anistiar suas nefastas práticas.

Comparada aos demais países latino-americanos, a situação brasileira nesta seara é deplorável. O Brasil limita-se às medidas de reparação econômica para com as vítimas da ditadura militar, como se a dignidade humana fosse transacionável. No lugar de uma justiça de transição real, tem-se aqui uma "justiça de transação". Em razão deste quadro, passaram-se mais de vinte anos da Constituição Cidadã e as feridas dos "anos de chumbo" continuam sangrando. Torturadores circulam impunemente pelas ruas, ocupando altas patentes e cargos públicos. Os arquivos da repressão continuam, durante todo este período "democrático", em sigilo absoluto, violando flagrantemente os princípios da publicidade e da transparência. Famílias não têm o sagrado direito de enterrar seus 
mortos. Mães não têm sequer um "pedacinho de osso" para depositar flores e fazer uma oração. Ao morrerem, não poderão ser sepultadas ao lado de seus filhos. A tortura, causa da morte de tantos que se opuseram ao regime, atualmente é estendida aos seus familiares por meio dos desaparecidos políticos. O povo brasileiro não possui o direito de conhecer a sua própria História. As instituições não foram reformadas, e, ainda hoje, as altas patentes militares, de quando em quando, pronunciam-se em defesa da maldição que assolou o país. Enquanto se desprezar uma justiça de transição efetiva, a ameaça sombria do pretérito subsistirá.

Por outro lado, o Caso Guerrilha do Araguaia x Brasil representa uma esperança na implantação de uma verdadeira justiça de transição no Brasil. A condenação do Estado brasileiro a investigar e processar os responsáveis por crimes contra a humanidade, a tornar públicas as informações referentes ao período obscuro - possibilitando a localização dos corpos desaparecidos - e a reformar as instituições estatais poderá ser o mais importante instrumento para concluir a transição jurídica do período autoritário para a democracia. Não se trata apenas de responsabilizar os autores de crimes contra a humanidade ou de pôr fim ao sigilo das informações referentes à ditadura militar. Trata-se de se pensar a sociedade que se pretende. Qual a importância dos direitos humanos na sociedade pretendida? Qual a importância dos direitos humanos nas Forças Armadas? O cidadão, na sociedade pretendida, pretende que as forças de segurança respeitem ou não a legalidade e os direitos humanos?

A não repetição de violações tão graves, bem como uma mudança de postura por parte das Forças Armadas, está vinculada à promoção de uma justiça de transição efetiva. É inadmissível que, depois de tudo que foi sistematicamente praticado contra parcela da população civil durante a ditadura militar, membros das Forças Armadas ainda manifestem-se favoravelmente ao golpe de 1964. Diferentemente de outros países, aqui 
nunca houve um pedido formal de desculpas. Por quê? A resposta é óbvia: porque fariam tudo de novo.

Também merece demasiada atenção a questão dos desaparecidos políticos no Brasil. Ainda há mais de uma centena de militantes que, presos pelas forças de segurança da ditadura, simplesmente sumiram, evaporaram, sem qualquer explicação oficial, sendo procurados até hoje pelos seus familiares. "Permanente é aquele crime cuja consumação se alonga no tempo, dependente da atividade do agente, que poderá cessar quando este quiser (cárcere privado, sequestro)." ${ }^{" 168}$ Se mortos estão os desaparecidos, como tudo indica, cabe aos responsáveis apontar o local do sepultamento, cessando a consumação das ocultações de cadáveres. Entretanto, mesmo com este elevado número de sequestros e/ou ocultações de cadáveres de perseguidos políticos cometidos neste exato momento, não há sequer um processo criminal visando apurar a responsabilidade destes delitos, ou até mesmo a localização dos corpos. Se permanentes são, não há proteção da Lei de Anistia, que só se refere aos crimes praticados durante o "período compreendido entre 02 de setembro de 1961 e 15 de agosto de 1979". Pergunta-se: Por que o Ministério Público nunca ofereceu denúncia sobre qualquer destes cento e tantos sequestros e/ou ocultações de cadáveres que continuam a ser praticados neste exato momento? A grande maioria deles, em verdade, foi parcialmente reconstituída por relatos de testemunhas e de outros presos, indicando inclusive os responsáveis pelos desaparecimentos. Ademais, se os indícios de autoria forem insuficientes, basta que se abram os arquivos militares para que tudo seja devidamente esclarecido. Perguntase novamente: Será necessária uma condenação na da Corte Interamericana de Direitos Humanos para que se cumpra a lei? Neste momento, surge outra grande desconfiança. Como o Estado brasileiro - especialmente o Supremo Tribunal Federal, última palavra do Judiciário - se posicionará face uma

\footnotetext{
${ }^{168}$ BITENCOURT, Cezar Roberto. Tratado de Direito Penal: parte geral 1. $15^{\mathrm{a}}$ ed. São Paulo: Saraiva, 2010. p. 254
} 
eventual sentença de procedência da Corte? Enfim, entre tantas perguntas, pode-se afirmar que a responsabilização criminal pelos sequestros e/ou ocultações de cadáveres dos desaparecidos políticos é o mínimo que a sociedade exige. Trata-se apenas da aplicação singela da lei. Ademais, esta responsabilização resolveria - pelo menos em parte - o problema dos desaparecidos políticos, uma vez que os responsáveis teriam que indicar o local do sepultamento, sob pena de responderem por sequestro e não por ocultação de cadáver, cuja pena é significativamente menor.

Resta então aguardar a iminente sentença da Corte Interamericana de Direitos Humanos. No caso de procedência, estará aberta uma oportunidade concreta para que a sociedade brasileira conclua o processo de transição para a democracia, extirpando os resquícios autoritários que nos prendem ao passado. É importante dizer que as torturas ainda existentes nas delegacias e presídios de todo o país nada mais são do que uma continuidade da conduta repressiva da ditadura, da mesma forma que a impunidade dos torturadores de ontem incentiva os de hoje. Para começar a mudar este cenário, necessárias se fazem as investigações dos crimes contra a humanidade, a abertura dos arquivos militares, a localização dos corpos, um pedido formal de desculpas das Forças Armadas e a instituição de cursos de direitos humanos nas três armas. Nada mais coerente, uma vez que na ditadura foram ministradas aulas de tortura nas dependências do Exército. Só assim as feridas deste período tão tenebroso serão cicatrizadas, beneficiando principalmente as gerações futuras, além das próprias Forças Armadas, cuja admiração à legalidade e aos direitos humanos restará desassociada dos "anos de chumbo". Atualmente, não houve qualquer sinal de mero arrependimento por parte das forças de segurança, apenas exortações ao período mais obscuro do país. Tristemente, parece inequívoco que Forças Armadas aderentes à vetusta "ideologia da segurança nacional" constituem uma ameaça à sociedade e à democracia, ainda hoje. 
Por fim, vale aqui afastar o entendimento de que uma eventual "revisão" da Lei de Anistia também deveria possibilitar a persecução penal dos crimes praticados pela resistência. Não bastassem todos os fundamentos já invocados, esta "revisão bilateral" não geraria efeitos para os crimes dos perseguidos políticos, sob pena de gravíssimo bis in idem. Os autores de crimes contra a ditadura militar foram barbaramente torturados, mortos, processados, condenados, passaram anos na prisão, exilados, banidos, tiveram parentes torturados e casas saqueadas. Já pagaram além da conta por seus delitos; de outra parte, os crimes praticados pelos agentes da repressão não foram sequer investigados. A ofensa à isonomia presente nesta afirmação é gritante.

Assim, este estudo buscou problematizar a questão da impunidade dos crimes contra a humanidade e a sua importância para a sociedade como um todo, ultrapassando e muito a esfera dos familiares e vítimas do regime militar. Trata-se de uma questão de Estado: apenas quando concluída esta transição jurídica - com a responsabilização dos autores de crimes contra a humanidade, o esclarecimento de todos os fatos obscuros (que têm revelado a ineficácia dos mecanismos de natureza civil para tais fins) e a reforma das instituições - a sociedade atingirá um verdadeiro patamar democrático, desamarrando-se de seu passado autoritário e fortalecendo-se para o futuro. $\mathrm{O}$ direito à verdade está intrinsecamente ligado ao direito à justiça, uma vez que sem uma investigação dos fatos nunca se chegará à verdade dos mesmos - embora alguns autores considerem que a persecução penal "satisfaz instintos de vingança de seus adversários, contribuindo para manter animosidades e dando à sociedade o perigoso sinal de que a violência se responde com violência."169 A verdade é que não se trata de revanchismo. Uma democracia não pode, nunca, jamais, ser complacente com golpes de Estado seguidos de violações tão cruéis aos direitos mais

\footnotetext{
169 DIMOULIS, Dimitri. Justiça de transição e função anistiante no Brasil. Hipostasiações indevidas e caminhos de responsabilização. p. 120
} 
humanos de parcela de sua população civil. É preferível fechar as portas de casa a deixar o monstro adormecido na varanda, mesmo que o ranger das portas desperte-o do sono. Em conclusão, a impunidade de violações tão graves constitui um péssimo legado para as próximas gerações. 


\section{BIBLIOGRAFIA}

ALVERGA, Alex Polari. Novas reflexões de Alex Polari sobre Stuart. In: CABRAL, Reinaldo; LAPA, Ronaldo (Org.). Desaparecidos Políticos: prisões seqüestros assassinatos. Rio de Janeiro: Comitê Brasileiro pela Anistia, 1979. p. 117-120

ARNS, Dom Paulo Evaristo. Prefácio. In: FAMILIARES DE MORTOS E DESAPARECIDOS POLÍTICOS. Dossiê dos Mortos e Desaparecidos a Partir de 1964. São Paulo: Imprensa Oficial do Estado, 1996. p. $22-24$

ARQUIDIOCESE DE SÃO PAULO. Brasil: nunca mais: um relato para a História. 15ª ed.. Petrópolis: Vozes, 1986. 312p.

BARCELLOS, Maria Auxiliadora Lara. Continuo sonhando. In: CAVALCANTI, Pedro Celso Uchoa; RAMOS, Jovelino (Org.). Memórias do exílio: Brasil 1964-19??. Lisboa: Arcádia, 1976. p. 315-319

BASTOS, Lucia Elena Ferreira. Anistia - As Leis Internacionais e o Caso Brasileiro. Curitiba: Juruá, 2009. 332p.

BATISTA, Nilo. Aspectos jurídico-penais da anistia. Revista de Direito Penal. Rio de Janeiro: Forense, n. 26, p. 33-42, jul./dez. 1979.

BATISTA, Nilo. Nota introdutória. In: DIMOULIS, Dimitri; MARTINS, Antonio; SWENSSON JUNIOR, Lauro Joppet (Org.). Justiça de Transição no Brasil: Direito, responsabilização e verdade. São Paulo: Saraiva, 2010. p. 7-17 
BICUDO, Hélio. Parecer sobre a anistia. Disponível em $<$ http://www.torturanuncamaisrj.org.br/artigos.asp?Codartigo=36\&Pesq=anistia>. Acessado em 29 ago. 2010.

BITENCOURT, Cezar Roberto. Tratado de Direito Penal: parte geral 1. $15^{\text {a }}$ ed. São Paulo: Saraiva, 2010. 853p.

BRASIL. Direito à Memória e à Verdade: Comissão Especial sobre Mortos e Desaparecidos Políticos. Brasília: Secretaria Especial dos Direitos Humanos, 2007. 500p

COIMBRA, Cecília Maria Bouças. Práticas psi e Tortura no Brasil. Revista Psicologia Política. São Paulo: SBPP, v.1, n. 2, p. 93-105, jul./dez. 2001.

COMISSÃO INTERAMERICANA DE DIREITOS HUMANOS. Demanda perante a Corte Interamericana de Direitos Humanos, Caso 11.552 - Julia Gomes Lund e outros (Guerrilha do Araguaia) Contra a República Federativa do Brasil. Revista anistia política e justiça de transição. Brasília: Ministério da Justiça, n. 2, p. 372-480, jul./dez. 2009.

COMITÊ BRASILEIRO PELA ANISTIA - RJ. A Questão dos Desaparecidos. In: CABRAL, Reinaldo; LAPA, Ronaldo (Org.). Desaparecidos Políticos: prisões seqüestros assassinatos. Rio de Janeiro: Comitê Brasileiro pela Anistia, 1979. p. 19-22

COMPARATO, Fábio Konder. A Afirmação Histórica dos Direitos Humanos. $4^{a}$ ed. São Paulo: Saraiva, 2005. 578p. 
COMPARATO, Fábio Konder. Crimes sem castigo. Disponível em $<$ http://www.jusbrasil.com.br/noticias/128879/artigo-crimes-sem-castigofabio-comparato>. Acesso em 29 ago. 2010.

COMPARATO, Fábio Konder; MONTEIRO, Maurício Gentil. Argüição de descumprimento fundamental. Revista $O A B / R J$. Rio de Janeiro, n. 2, v. 25, p. 213-236, jul./dez. 2009.

DIMOULIS, Dimitri. Justiça de transição e função anistiante no Brasil. Hipostasiações indevidas e caminhos de responsabilização. In: DIMOULIS, Dimitri; MARTINS, Antonio; SWENSSON JUNIOR, Lauro Joppet (Org.). Justiça de Transição no Brasil: Direito, responsabilização e verdade. São Paulo: Saraiva, 2010. p. 91-127

FÁVERO, Eugênia Augusta Gonzaga; WEICHERT, Marlon Alberto. Anistia, tortura, república e democracia. Disponível em <http://www.oabsp.org.br/noticias/2010/02/12/5950>. Acesso em 29 ago. 2010.

FÁVERO, Eugênia Augusta Gonzaga; WEICHERT, Marlon Alberto. Texto base sobre responsabilidade criminal. Disponível em <http://www.prr3.mpf.gov.br/component/option,com_remository/Itemid,68/ func,download/id,1615/chk,1835da563757fe01537d244ee4e80bbb/no_html ,1/>. Acesso em 12 out. 2010.

FELIPPE, Marcio Sotelo. Lei de anistia foi estratégia da ditadura. Disponível em <http://www.conjur.com.br/2010-maio-07/lei-anistia-foiapenas-produto-estrategia-politica-ditadura>. Acesso em 12 set. 2010. 
FERRAZ JR, Tércio Sampaio. Revisão para tudo ficar como está? Disponível em <http://www. terciosampaioferrazjr.com.br/?q=/publicacoescientificas/69>. Acesso em 4 set. 2010.

FERREIRA, José Ignácio. Anistia: caminho e solução. Vitória: Janc, 1979. 120p.

FILHO, Vladimir Brega; SANTOS, Roberto Lima. Os reflexos da "judicialização" da repressão política no Brasil no seu engajamento com os postulados da justiça de transição. Revista anistia política e justiça de transição. Brasília: Ministério da Justiça, n. 1, p. 152-177, jan./jun. 2009.

GASPARI, Elio. A ditadura envergonhada. São Paulo: Companhia das Letras, 2002. 424p.

GASPARI, Elio. A ditadura escancarada. São Paulo: Companhia das Letras, 2002.507p.

GOMES, Luiz Flávio. Lei de anistia: brilharam pela ausência as $\begin{array}{lllll}\text { vítimas } e & \text { seus direitos. Disponível em }\end{array}$ $<\mathrm{http} / / / \mathrm{www}$.novacriminologia.com.br/artigos/artigoler.asp?idartigo=2700> . Acesso em 28 ago. 2010.

INTERNACIONAL CENTER FOR TRANSITIONAL JUSTICE. Parecer técnico sobre a natureza dos crimes de lesa-humanidade, a imprescritibilidade de alguns delitos e a proibição de anistias. Revista anistia política e justiça de transição. Brasília: Ministério da Justiça, n. 1, p. 352-394, jan./jun. 2009.

GUARANY, Reinaldo. A fuga. São Paulo: Brasiliense, 1984. 155p. 
MARINHO, Roberto. O Julgamento da Revolução. O Globo, Rio de Janeiro, p.1, 7 out. 1984.

MARTINS, Roberto Ribeiro. Anistia ontem e hoje. $3^{\mathrm{a}}$ ed. São Paulo: Brasiliense, 2010. 262p.

MELLO, Celso D. de Albuquerque. Curso de Direito Internacional Público. v. 1. 14 ed.. Rio de Janeiro: Renovar, 2002. 898p.

MIRABETE, Julio Fabbrini. Manual de Direito Penal. $23^{\mathrm{a}}$ ed. São Paulo: Atlas, 2006. 450p.

NETO, José Genoino. A Guerrilha do Araguaia. In: CABRAL, Reinaldo; LAPA, Ronaldo (Org.). Desaparecidos Políticos: prisões seqüestros assassinatos. Rio de Janeiro: Comitê Brasileiro pela Anistia, 1979. p. $260-262$

PIOVESAN, Flávia. Direitos Humanos e Justiça Internacional: Um estudo comparativo dos sistemas regionais europeu, interamericano e africano. São Paulo: Saraiva, 2007. 280p.

PIOVESAN, Flávia. Direitos Humanos e o Direito Constitucional Internacional. $11^{\mathrm{a}}$ ed. São Paulo: Saraiva, 2010. 608p.

PIOVESAN, Flávia. Direito internacional dos direitos humanos e lei de anistia: o caso brasileiro. Revista anistia política e justiça de transição. Brasília: Ministério da Justiça, n. 2, p. 176-189, jul./dez. 2009. 
PIOVESAN, Flávia. Introdução ao sistema interamericano de proteção dos direitos humanos: a Convenção Americana de Direitos Humanos. In: GOMES, Luiz Flávio; PIOVESAN, Flávia (Org.). O Sistema Interamericano de Proteção dos Direitos Humanos e o Direito Brasileiro. São Paulo: Revista dos Tribunais, 2000. p. 17-52

PIOVESAN, Flávia. Temas de Direitos Humanos. $4^{\mathrm{a}}$ ed. São Paulo: Saraiva, 2010. 487p.

PLASSAT, Frei Xavier. A tortura e a morte de Tito. In: CAVALCANTI, Pedro Celso Uchoa; RAMOS, Jovelino (Org.). Memórias do exílio: Brasil 1964-19??. Lisboa: Arcádia, 1976. p. 357-362

POTTER, Philip. Prefácio. In: ARQUIDIOCESE DE SÃO PAULO. Brasil: nunca mais: um relato para a História. $15^{\mathrm{a}}$ ed. Petrópolis: Vozes, 1986. p. $15-19$

RAMOS, André de Carvalho. O Diálogo das Cortes: O Supremo Tribunal Federal e a Corte Interamericana de Direitos Humanos. In: JUBILUT, Liliana Lyra; JUNIOR, Alberto do Amaral (org.). O STF e o Direito Internacional dos Direitos Humanos. São Paulo: Quartier Latin, 2009. p. $805-850$

RAMOS, André de Carvalho. Processo internacional de direitos humanos: Análise dos sistemas de apuração de violações de direitos humanos e a implementação das decisões no Brasil. Rio de Janeiro: Renovar, 2002. 433p.

RAMOS, André de Carvalho. Responsabilidade internacional por violação de direitos humanos: Seus elementos, a reparação devida e 
sanções possíveis: Teoria e prática do Direito Internacional. Rio de Janeiro: Renovar, 2004. 452p.

SILVA, Alexandre Garrido da; VIEIRA, José Ribas. Justiça transicional, direitos humanos e a seletividade do ativismo judicial no Brasil. Revista anistia política e justiça de transição. Brasília: Ministério da Justiça, n. 2, p. 234-267, jul./dez. 2009.

SILVA, José Afonso da. Curso de Direito Constitucional Positivo. $27^{a}$ Ed. São Paulo: Malheiros, 2006. 924p.

STF, ADPF nº 153/DF, Rel. Ministro Eros Grau, Brasília, 29 abr. 2010

STF, Ext n 1085 , Rel. Ministro Gilmar Mendes, Brasília, 16 dez. 2009.

STF, Ext n 855, Rel. Ministro Celso de Mello, Brasília, 26 ago. 2004.

STRECK, Lenio. A Lei de Anistia, a Constituição e os Direitos Humanos no Brasil: Lenio Streck Responde. Revista anistia política e justiça de transição. Brasília: Ministério da Justiça, n. 2, p. 24-29, jul./dez. 2009.

SWENSSON JUNIOR, Lauro Joppert. Anistia Penal: Problemas de Validade Da Lei de Anistia Brasileira (Lei 6.683/79). Curitiba: Juruá, 2007. $232 p$. 
SWENSSON JUNIOR, Lauro Joppert. Positivismo, realismo e moralismo jurídicos no debate sobre a responsabilização penal para os crimes da ditadura militar: Revista anistia política e justiça de transição: Ministério da Justiça. Brasília, n. 2, p. 322-342, jul./dez. 2009.

TOURINHO FILHO, Fernando da Costa. Manual de processo penal. São Paulo: Saraiva, 2001. 686p.

VENTURA, Deisy et al. O Manifesto dos juristas. Disponível em $<$ http://www.torturanuncamaisrj.org.br/noticias.asp?Codnoticia=184\&ecg=>. Acesso em 4 set. 2010.

ZELIC, Marcelo. A auto-anistia e a farsa de um acordo nacional. Disponível em <http://www.torturanuncamaisrj.org.br/artigos.asp?Codartigo=83\&ecg=0> . Acesso em 4 set. 2010 . 